\title{
The intestinal barrier as an emerging target in the toxicological assessment of mycotoxins
}

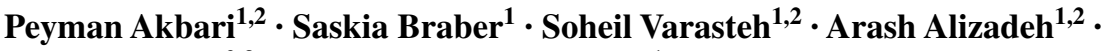 \\ Johan Garssen $^{2,3} \cdot$ Johanna Fink-Gremmels ${ }^{1}$
}

Received: 11 February 2016 / Accepted: 5 July 2016 / Published online: 14 July 2016

(C) The Author(s) 2016. This article is published with open access at Springerlink.com

\begin{abstract}
Mycotoxins, the secondary metabolites of fungal species, are the most frequently occurring natural food contaminants in human and animal diets. Risk assessment of mycotoxins focused as yet on their mutagenic, genotoxic and potential carcinogenic effects. Recently, there is an increasing awareness of the adverse effects of various mycotoxins on vulnerable structures in the intestines. In particular, an impairment of the barrier function of the epithelial lining cells and the sealing tight junction proteins has been noted, as this could result in an increased translocation of luminal antigens and pathogens and an excessive activation of the immune system. The current review aims to provide a summary of the available evidence regarding direct effects of various mycotoxins on the intestinal epithelial barrier. Available data, based on different cellular and animal studies, show that food-associated exposure to certain mycotoxins, especially trichothecenes and patulin, affects the intestinal barrier integrity and can result in an increased translocation of harmful stressors. It is therefore hypothesized that human exposure to certain mycotoxins, particularly deoxynivalenol,
\end{abstract}

Electronic supplementary material The online version of this article (doi:10.1007/s00204-016-1794-8) contains supplementary material, which is available to authorized users.

Saskia Braber

s.braber@uu.nl

1 Division of Veterinary Pharmacology, Pharmacotherapy and Toxicology, Institute for Risk Assessment Sciences, Utrecht University, Yalelaan 104, 3584 CM Utrecht, The Netherlands

2 Division of Pharmacology, Utrecht Institute for Pharmaceutical Sciences, Faculty of Science, Utrecht University, 3584 CG Utrecht, The Netherlands

3 Nutricia Research, 3584 CT Utrecht, The Netherlands as the major trichothecene, may play an important role in etiology of various chronic intestinal inflammatory diseases, such as inflammatory bowel disease, and in the prevalence of food allergies, particularly in children.

Keywords Mycotoxins · Tight junction proteins · Intestinal permeability $\cdot$ Mucosal inflammation

\begin{tabular}{|c|c|}
\hline \multicolumn{2}{|c|}{ Abbreviations } \\
\hline 3-Ac-DON & 3-Acetyl deoxynivalenol \\
\hline 15-Ac-DON & 15-Acetyl deoxynivalenol \\
\hline $\mathrm{AFB}_{1}$ & Aflatoxin $\mathrm{B}_{1}$ \\
\hline $\mathrm{AFM}_{1}$ & Aflatoxin $\mathrm{M}_{1}$ \\
\hline$\alpha-\mathrm{ZOL}$ & Alpha-zearalenol \\
\hline$\beta-\mathrm{ZOL}$ & Beta-zearalenol \\
\hline BEN & Balkan endemic nephropathy \\
\hline CLDNs & Claudins \\
\hline CYP & Cytochrome P450 \\
\hline DON & Deoxynivalenol \\
\hline ERK1/2 & $\begin{array}{l}\text { Extracellular signal-regulated kinase } 1 \text { and } \\
2\end{array}$ \\
\hline $\mathrm{FB}_{1}$ & Fumonisin $B_{1}$ \\
\hline FITC & Fluorescein isothiocyanate \\
\hline GI tract & Gastrointestinal tract \\
\hline GSH & Glutathione \\
\hline HRP & Horseradish peroxidase \\
\hline IEC & Intestinal epithelial cell \\
\hline IARC & International agency for research on cancer \\
\hline iNOS & Inducible nitric oxide synthase \\
\hline JAM & Junctional adhesion molecule \\
\hline JNK & c-Jun N-terminal kinase \\
\hline LY & Lucifer yellow \\
\hline MAPKs & Mitogen-activated protein kinases \\
\hline NIV & Nivalenol \\
\hline OCLN & Occludin \\
\hline
\end{tabular}




$\begin{array}{ll}\text { OTA } & \text { Ochratoxin A } \\ \text { PAT } & \text { Patulin } \\ \text { ROS } & \text { Reactive oxygen species } \\ \text { RNS } & \text { Reactive nitrogen species } \\ \text { TEER } & \text { Transepithelial electrical resistance } \\ \text { TJs } & \text { Tight junction proteins } \\ \text { ZEA } & \text { Zearalenone } \\ \text { ZO } & \text { Zonula occludens }\end{array}$

\section{Introduction}

Since the early discovery of aflatoxins as food and feed contaminants, risk assessment of mycotoxin exposure has been initially focused on their mutagenic, genotoxic and potentially carcinogenic effects, as major human health risks (Bennett and Klich 2003; Liu and Wu 2010; Wu et al. 2014a). More recently, there is an increasing awareness of the adverse effects of various mycotoxins on vulnerable structures in the intestines and the impairment of intestinal integrity (Bouhet and Oswald 2005; Grenier and Applegate 2013; Maresca et al. 2008; Pinton and Oswald 2014). A compromised barrier function is associated with an increased epithelial permeability and translocation of luminal allergens and pathogens, as well as a non-specific inflammatory response and an overstimulation of the gutassociated immune system (DeMeo et al. 2002; Groschwitz and Hogan 2009; Odenwald and Turner 2013; Pastorelli et al. 2013). The most prominent example of a mycotoxin primarily associated with an impairment of the intestinal integrity is deoxynivalenol, a trichothecene, which first had been recognized for its pro-inflammatory and immunomodulatory activities (Pestka et al. 1990; Pestka 2010a, b; Rotter et al. 1996). However, various other mycotoxins have been studied regarding their effects on the intestinal barrier, both in vitro as well as in vivo. The current review aims to provide a summary and discussion of the available evidence regarding direct effects of various mycotoxins on individual structures of the intestinal epithelial barrier. The mycotoxins addressed include the aflatoxins, zearalenone, ochratoxins, fumonisins and patulin, as well as T-2/HT-2 toxin, nivalenol and deoxynivalenol, as representatives of the class of the trichothecenes. The summary of the effects of individual mycotoxins on the intestinal barrier is preceded by a short introduction into common experimental models and test parameters to measure intestinal integrity.

\section{Experimental models used to assess intestinal permeability}

\section{The Caco-2 cell model}

During the last few decades, the use of different intestinal epithelial cell lines from various animal species as well as from human origin has been used to assess the effects of drugs and toxins on the permeability of the intestinal epithelium. Among them, the Caco-2 cell line $\left(\mathrm{ATCC}^{\circledR}\right.$ number: HTB-37), originally isolated from a human colon adenocarcinoma, is well accepted as a reference model to conduct transport studies as well as to investigate the effects on barrier function. Caco-2 cells are routinely cultivated as monolayers on permeable filters. During culturing, they undergo spontaneous differentiation resulting in polarization and formation of the tight junction (TJ) proteins between adjacent cells. Differentiated Caco-2 cells form polarized apical/mucosal and basolateral/serosal membranes that are impermeable and are structurally and functionally similar to epithelial cells of the small intestine (Artursson et al. 2012; Hidalgo et al. 1989; Sambuy et al. 2005; Sun and Pang 2007). A major advantage of the common technique to grow Caco- 2 cells on transwell inserts is the fact that transport of drugs and toxins from the apical to the basolateral compartment can be measured. In turn, the established cell monolayer can be challenged from the apical (luminal) site as well as the basolateral site with toxins as well as other antigens and allow a wide range of functional parameters to be measured (Shimizu 2010; Sun et al. 2008; Sun and Pang 2007). In addition, this Caco-2 cell system is a commonly used model to study the rate of absorption and excretion of mycotoxins across the intestinal epithelium (Berger et al. 2003; Caloni et al. 2005, 2006; Pfeiffer et al. 2011; Schrickx et al. 2006; Tep et al. 2007; Videmann et al. 2007, 2009). Although the epithelial permeability for individual mycotoxins is beyond the scope of this review, the transepithelial transport of different mycotoxins has been briefly described and summarized in Electronic Supplementary Material, Table 1.

\section{Measurement of transepithelial electrical resistance (TEER)}

TEER is the first parameter measured to evaluate the integrity of the epithelial barrier in the Caco-2 cell model. A simple voltmeter device equipped with a pair of chopsticklike electrodes quantifies ion movement across a monolayer and is considered as an effective indicator for the developing barrier function. TEER is generally used to follow the cell differentiation process, and standard values for a completed non-permeable barrier are established based on individual devices and insert sizes. Even though TEER measurement is quick and easy and can be repeated as needed, it remains a non-specific endpoint. Routine TEER measurement is used to control the integrity of the epithelial layer in an experimental setting and as a first indicator of toxininduced damages. However, no specific mechanisms and transport processes can be attributed to changes in TEER without further investigations. In comparison with the 
Table 1 Modulation of the intestinal barrier function by aflatoxins

\begin{tabular}{|c|c|c|c|}
\hline Model & Concentration and exposure time & Effects on barrier function & References \\
\hline \multicolumn{4}{|l|}{ Aflatoxin } \\
\hline Caco- 2 cells & $\begin{array}{l}150 \mu \mathrm{M} \\
72 \mathrm{~h}\end{array}$ & $\mathrm{AFB}_{1}$ : decrease in TEER values & Gratz et al. (2007) \\
\hline Caco- 2 cells & $\begin{array}{l}1-100 \mu \mathrm{M} \\
7 \text { days }\end{array}$ & $\begin{array}{l}\mathrm{AFB}_{1}: \text { decrease in TEER values } \\
\text { Decrease in transcript level of CLDN3 and OCLN }\end{array}$ & Romero et al. (2016) \\
\hline Broiler chicken & $\begin{array}{l}1.5 \mathrm{mg} / \mathrm{kg} \text { bw } \\
20 \text { days }\end{array}$ & $\begin{array}{l}\mathrm{AFB}_{1} \text { : increase in transcript level of CLDN1 and CLDN2 } \\
\text { Increase in the plasma lactulose to rhamnose ratio }\end{array}$ & Chen et al. (2016) \\
\hline Caco- 2 cells & $\begin{array}{l}3.2-33 \mathrm{nM} \\
24 \mathrm{~h}\end{array}$ & $\mathrm{AFM}_{1}:$ decrease in TEER values & Caloni et al. (2012) \\
\hline
\end{tabular}

standard TEER assay, real-time cell electronic sensing was further developed. This technique is based on the continuous recording of cellular horizontal impedance, which enables a real-time monitoring of the integrity of the epithelial barrier and the potential effects of toxins and other agents that affect barrier integrity (Abassi et al. 2009; Akbari et al. 2014; Benson et al. 2013; Sun et al. 2012).

\section{Paracellular tracer flux assays}

In addition to TEER measurement, determination of the paracellular flux of marker substances across the cell monolayer can be monitored (De Walle et al. 2010). These markers differ in size and need to be non-toxic, noncharged and water soluble, and they should neither be absorbed, nor metabolized by the cells (Arrieta et al. 2006; Bjarnason et al. 1995). The most common paracellular markers used in in vitro models are fluorescent compounds (such as lucifer yellow, LY) or fluorescently labeled compounds (such as fluorescein isothiocyanate (FITC)-dextran and FITC-inulin) (Jimison et al. 2012). In particular, apical-to-basolateral flux of paracellular markers is used to identify a compromised intestinal barrier function (Bischoff et al. 2014).

Paracellular tracer transport can also be measured in in vivo models by testing the presence of macromolecular tracers in the blood (such as FITC-dextran) after oral gavage. In addition, site-specific permeability alongside the gastrointestinal (GI) tract can be assessed by measuring the presence of a variety of small saccharide probes and/ or chromium-labeled ethylenediaminetetraacetic acid (CrEDTA) in the urine of humans and experimental animals after oral administration. For example, sucrose and lactulose/mannitol are useful probes for determining permeability characteristics of the gastroduodenal region and the entire small intestine, while sucralose and Cr-EDTA are used to evaluate colonic permeability (Arrieta et al. 2006; Bjarnason et al. 1995; Meddings and Gibbons 1998).

\section{Assessment of the expression of TJ proteins}

The major functional elements of the epithelial barrier are the TJ proteins, sealing the intercellular space between adherent epithelial cells (Groschwitz and Hogan 2009; Peterson and Artis 2014). TJs form an anastomosing network near the luminal surface, thus preventing a paracellular transport of luminal antigens (Fig. 1). TJs are composed of: I) transmembrane proteins whose extracellular domains cross the plasma membrane and interact with their partners on the adjacent cells and II) cytoplasmic scaffolding proteins, which are entirely located on the intracellular side of the plasma membrane. Transmembrane TJs form a horizontal barrier at the apical-lateral membrane of epithelial cells and consist of occludin (OCLN), claudins (CLDNs), junctional adhesion molecules (JAMs) and tricellulin. The cytoplasmic scaffolding proteins, like zonula occludens (ZOs) proteins, provide a direct link between transmembrane TJ proteins and the actin cytoskeleton (Chiba et al. 2008; Schneeberger and Lynch 2004; Tsukita et al. 2001). Increased TJ mRNA expression can indicate ongoing repair mechanisms in an established epithelial cell monolayer (Akbari et al. 2014). However, the assessment of TJs should not be limited to the gene level, since mRNA amount does not necessarily predict the protein level (Schwanhausser et al. 2011; Vogel et al. 2010). For example, our study showed that following deoxynivalenol exposure, a decrease in the protein level of CLDNs could be observed, associated with an up-regulation of the mRNA level of CLDNs (Akbari et al. 2014). Therefore, for the interpretation of barrier damage, qPCR and Western blot analysis are generally performed in parallel to measure mRNA and protein levels of TJs, respectively. In addition, the visualization of the subcellular localization of TJs by immunostaining is an additional tool to identify intestinal barrier dysfunction. All these measurements can be taken in different in vitro cell culture models as well as in intestinal explants and in vivo models. 


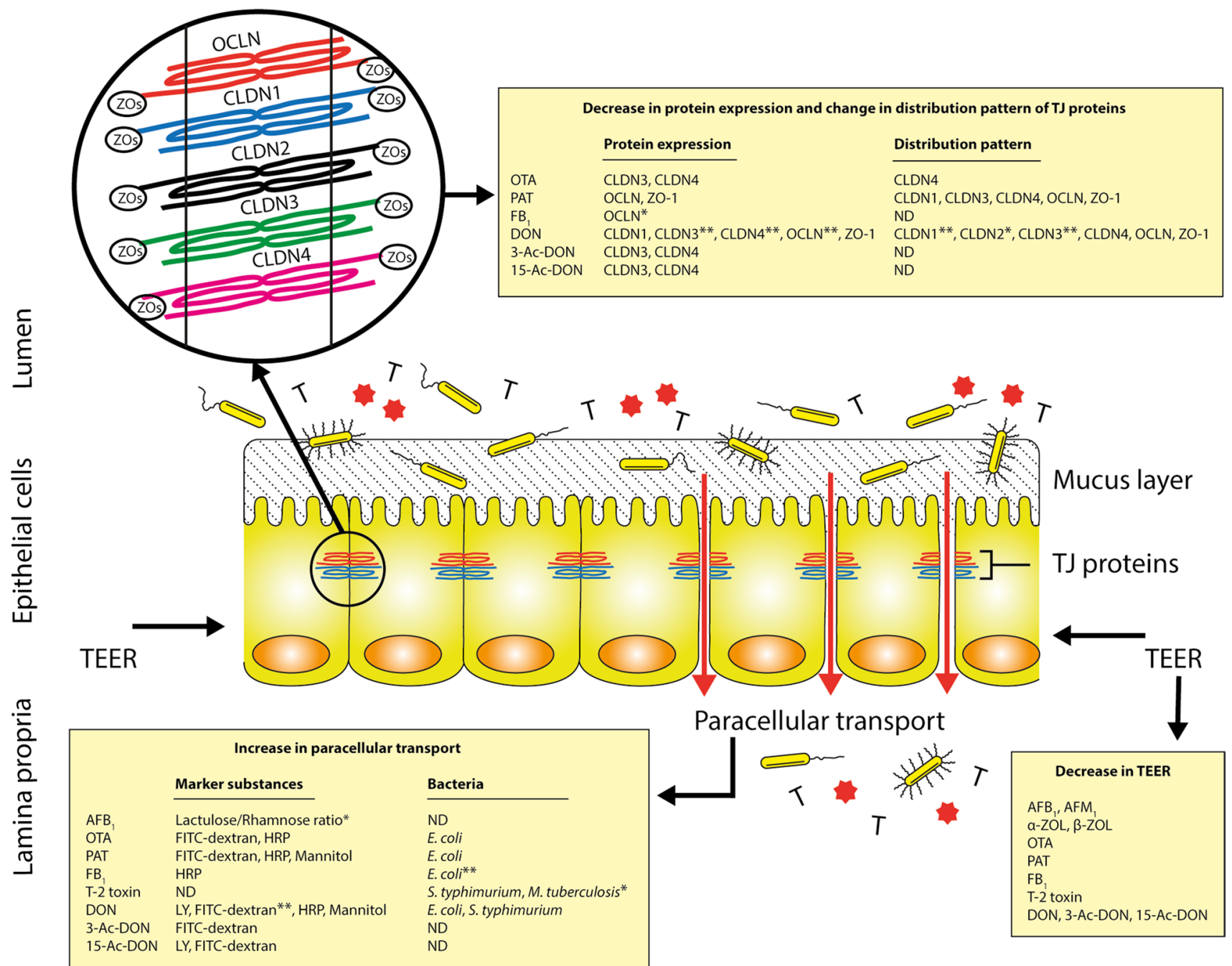

Fig. 1 Schematic illustration of the mycotoxin-induced intestinal epithelial barrier breakdown. The gut mucosa is constantly challenged by a diverse microbial community ( borne toxins $(\mathrm{T})$ and foreign antigens ( $)$. The most prominent examples of food-borne toxins primarily associated with an impairment of the intestinal barrier are mycotoxins. Various mycotoxins have been shown to induce intestinal barrier breakdown demonstrated by a decrease in TEER, an increase in paracellular transport and changes in the expression as well as distribution pattern of different TJ proteins. The data shown in the figure have been demonstrated by in vitro studies unless otherwise stated (*in vivo studies,

\section{Intestinal explant model}

Next to cell culture models, intestinal explants have been introduced as a model to test intestinal integrity. The model is based on the long-term experience with intestinal specimen mounted in the so-called Ussing chambers for the study of nutrient absorption. For these studies, sheets of intestinal segments are mounted in Ussing chambers and maintained in complete explant culture medium gassed with $95 \% \mathrm{O}_{2}$ and $5 \% \mathrm{CO}_{2}$ and kept at $37{ }^{\circ} \mathrm{C}$ with or **in vitro as well as in vivo studies). Abbreviations used: $3-A c-D O N$ 3-acetyl deoxynivalenol, 15-Ac-DON 15-acetyl deoxynivalenol, $A F B_{I}$ aflatoxin $\mathrm{B}_{1}, A F M_{1}$ aflatoxin $\mathrm{M}_{1}, \alpha-Z O L$ alpha-zearalenol, $\beta-Z O L$ beta-zearalenol, CLDNs claudins, DON deoxynivalenol, E. coli Escherichia coli, $F B_{1}$ fumonisin $\mathrm{B}_{1}$, FITC-dextran fluorescein isothiocyanate-dextran, $H R P$ horseradish peroxidase, $L Y$ lucifer yellow, M. tuberculosiss Mycobacterium tuberculosiss, $N D$ not determined, OCLN occludin, OTA ochratoxin A, PAT patulin, S. typhimurium Salmonella typhimurium, TEER transepithelial electrical resistance, TJ tight junction, ZOs zonula occludens

without shaking for the entire culture time (Kolf-Clauw et al. 2009). The major advantage of this model is that explants maintain the complex cellular community and intestinal architecture, and therefore, cell-cell interactions can be studied. Moreover, segment-specific responses can be monitored alongside the GI tract. The main limitation of intestinal explant is that the period of culture during which the morphology and function of cells is preserved is very short, limiting the possibility to study delayed or long-term effects (Kolf-Clauw et al. 2009, 2013; Randall et al. 2011). 


\section{In vivo models}

In addition to the above-described in vitro (cell culture) or ex vivo (explant) assays, several markers of intestinal integrity can be directly measured in vivo in comparable models. This includes the paracellular flux assays and the assessment of the expression of TJ proteins together with histological approaches that provide insight into changes in the intestinal architecture, but also into epithelial cell damage (Bischoff et al. 2014). Zonulin, as an example, is a physiological modulator of intercellular TJs, and an increase in zonulin levels in serum is associated with an impaired intestinal permeability (Fasano 2011, 2012). Moreover, to identify the intestinal epithelial damage, serum concentrations of intestinal fatty acid-binding protein (IFABP) can be evaluated (Furuhashi and Hotamisligil 2008; Pelsers et al. 2003), but both parameters have not been widely applied in the assessment of mycotoxins. In contrast, histological investigations describing the effects of mycotoxins on villus architecture, goblet cells and mucus production (Paneth cells) are among routine approaches to detect the presence and the extent of epithelial cell damage and intestinal integrity following the exposure to mycotoxins and other toxic agents in various animal species (Bischoff et al. 2014; Blikslager et al. 2007; Cheat et al. 2015; Pinton et al. 2015).

\section{Effects of mycotoxins on intestinal permeability}

Figure 1 provides a comprehensive overview of the available evidence regarding direct effects of various mycotoxins on the intestinal epithelial barrier. The direct effect of aflatoxins, zearalenone, ochratoxin $\mathrm{A}$, patulin, fumonisin $\mathrm{B}_{1}$, T-2/HT-2 toxin, nivalenol and deoxynivalenol are extensively explained and discussed in the following section.

\section{Aflatoxins}

Aflatoxins are naturally occurring mycotoxins that are produced by various species of Aspergillus. The major aflatoxins commonly isolated from foods and feeds are aflatoxins $B_{1}, B_{2}, G_{1}$ and $G_{2}$ (Leong et al. 2012). Aflatoxin $B_{1}\left(A_{F B}\right)$, considered as the most toxic form, is metabolized by liver cytochrome P450 (CYP) enzymes (mainly by CYP3A4 and CYP1A2) to an $\mathrm{AFB}_{1}$-8,9-exo-epoxide and $\mathrm{AFB}_{1}$-8,9-endoepoxide. The exo-epoxide rapidly binds to DNA and forms the 8,9-dihydro-8-(N7-guanyl)-9-hydroxy $\mathrm{AFB}_{1}$ (AFB $_{1^{-}}$ N7-Gua) adduct. If this DNA damage is not repaired before DNA replication, it causes mutational effects in the third base of codon 249 in the p53 tumor suppressor gene. P53 is the most frequently targeted gene in human carcinogenesis, with a mutation frequency of $50 \%$ in most major cancers (Bedard and Massey 2006; Hamid et al. 2013; Wild and
Turner 2002); hence, this mutation is considered as a key event in aflatoxin-induced carcinogenesis. The endo-epoxide primarily binds to cellular proteins and is associated with direct cytotoxicity and the impairment of liver function. $\mathrm{AFB}_{1}$ is classified as a group 1 carcinogen (carcinogenic to humans) by the International Agency for Research on Cancer (IARC) (IARC 2002). Epidemiological evidence suggest a synergistic effect of aflatoxin $\mathrm{B}_{1}$ and chronic hepatitis $B$ virus infections in the prevalence of liver cancer in humans (Liu et al. 2012; Nordenstedt et al. 2010; Wild and Turner 2002; Wu and Santella 2012).

Another important hepatic metabolite of $\mathrm{AFB}_{1}$ is aflatoxin $\mathrm{M}_{1}\left(\mathrm{AFM}_{1}\right)$, which is excreted into milk both in animals and in humans. This results in an undesirable exposure of infants. $\mathrm{AFM}_{1}$ is less biologically active than $\mathrm{AFB}_{1}$, but can also be converted into an $\mathrm{AFM}_{1}$-epoxide that can bind to DNA and form a $\mathrm{AFM}_{1}$-N7-Gua which leads to hepatotoxicity and hepato-carcinogenicity (Egner et al. 2003; Leong et al. 2012; Marin et al. 2013). IARC has classified $\mathrm{AFM}_{1}$ as a group $2 \mathrm{~B}$ carcinogen (possibly carcinogenic to humans) (IARC 2002).

\section{Effects of aflatoxins on intestinal barrier function}

In consideration of the primary hepatotoxicity and hepatocarcinogenicity, only very few studies have been conducted showing that aflatoxins exposure might compromise also intestinal permeability (Table 1). Gratz et al. (Gratz et al. 2007) showed that $\mathrm{AFB}_{1}$ induces a timedependent decrease in TEER values of Caco- 2 cells. This effect was only observed at high concentrations and in the presence of activated CYP3A4, confirming the biotransformation-dependent toxicity of $\mathrm{AFB}_{1}$. Recently, it has been reported that the TEER decrease in $\mathrm{AFB}_{1}$-exposed Caco- 2 cells at concentrations up to $100 \mu \mathrm{M}$ for 7 days is accompanied with a decrease in transcript level of CLDN3 and OCLN, while the level of CLDN4 remained unaffected (Romero et al. 2016). Contradictory results have been observed in in vivo models, since Galarza-Seeber et al. observed that $\mathrm{AFB}_{1}$ does not increase gut permeability in broiler chickens, whereas a study conducted by Chen et al. clearly showed that $\mathrm{AFB}_{1}$ affects intestinal barrier function in broiler chickens as indicated by an increase in the plasma lactulose to rhamnose ratio (L/R ratio) as well as an increase in transcript level of CLDN1 and CLDN2 in the jejunum (Chen et al. 2016; Galarza-Seeber et al. 2016). It has been demonstrated that exposure to much lower $\mathrm{AFM}_{1}$ concentrations either to the apical or basolateral surface of the Caco-2 cell monolayer results in a slight, but significant TEER decrease (Caloni et al. 2012). The subcellular localization of OCLN and ZO-1 remained unaffected as observed by immunostaining. Further studies would be necessary to unravel the potential clinical impact 
of aflatoxins, in particular $\mathrm{AFM}_{1}$, on epithelial barrier integrity in infants.

\section{Zearalenone}

Zearalenone (ZEA) is a non-steroidal estrogenic mycotoxin produced by various Fusarium species (Marin et al. 2013). Following oral exposure, absorbed ZEA is predominantly metabolized into alpha-zearalenol $(\alpha-Z O L)$ and beta-zearalenol ( $\beta$-ZOL) by hepatic hydroxysteroid dehydrogenases (Kleinova et al. 2002; Malekinejad et al. 2005, 2006a, b; Warth et al. 2013). The reproductive system is the major target organ for ZEA and its metabolites, which are implicated in reproductive disorders and hyperestrogenic syndromes in animals and humans (Malekinejad et al. 2006b, 2007; Minervini and Dell'Aquila 2008; Schoevers et al. 2012; Zinedine et al. 2007). The main mechanism of action for the estrogenic effects of ZEA is the ability of this mycotoxin to bind and activate estrogenic receptors (ERs), in particular ER $\alpha$ and $E R \beta$ (Minervini and Dell'Aquila 2008; Takemura et al. 2007). In addition, ZEA is believed to induce cytotoxic, hepatotoxic, hematotoxic, immunotoxic and genotoxic effects, which are probably related to intracellular oxidative stress generated by ZEA leading to oxidative DNA damage and cellular apoptosis (Abid-Essefi et al. 2004; Hassen et al. 2007; Liu et al. 2014; Marin et al. 2011; Pfohl-Leszkowicz et al. 1995; Zinedine et al. 2007). DNA adduct formation induced by ZEA has been occasionally reported in in vitro as well as in vivo models (AbidEssefi et al. 2003; Pfohl-Leszkowicz et al. 1995; Zinedine et al. 2007). However, IARC has classified ZEA as a group 3 carcinogen (not carcinogenic to humans) due to inadequate evidence for the carcinogenicity of ZEA in humans (IARC 1987).

\section{Effects of zearalenone on intestinal barrier function}

It is known that ZEA can induce cytotoxic and apoptotic effects on human enterocytes (Abid-Essefi et al. 2003, 2004; Calvert et al. 2005; Kouadio et al. 2005); however, the effect of ZEA on intestinal barrier has not been extensively studied (Table 2). It has recently been reported that ZEA has no effect on TEER values of IPEC-1 cells, whereas exposure to $\alpha-\mathrm{ZOL}$ and $\beta$-ZOL causes a dramatic decrease in TEER levels in a time-dependent manner (Marin et al. 2015). Another study has shown that the exposure of rats to ZEA $(0.3-146 \mathrm{mg} / \mathrm{kg}$ bw) for 7 days results in a down-regulation of CLDN4 and OCLN mRNA expression in the jejunum (Liu et al. 2014). Further research is needed to extend the current knowledge of impairment of intestinal barrier function induced by ZAE as well as its metabolites.

\section{Ochratoxin A}

Ochratoxin A (OTA) is a mycotoxin produced by various species of Aspergillus and Penicillium (Marin et al. 2013). Exposure to OTA is a worldwide phenomenon, as evidenced by the presence of OTA in the majority of the tested human blood samples in many countries (Peraica et al. 2001; Pfohl-Leszkowicz and Manderville 2007; StuderRohr et al. 2000). The kidney is the major target organ for OTA and its derivatives, and some epidemiological studies in humans have associated the exposure to OTA with a chronic tubulo-interstitial nephritis (also denoted Balkan endemic nephropathy (BEN)) and urothelial tract tumors (Fink-Gremmels 2005; Grollman and Jelakovic 2007; Marin et al. 2013). At higher concentrations, OTA has been shown to be nephrotoxic, teratogenic and immunotoxic. IARC has classified OTA as a group 2B carcinogen (possibly carcinogenic to humans) on the basis of sufficient evidence for carcinogenicity in animal studies (IARC 2002). A number of mechanisms are described to be involved in OTA toxicity, including (1) inhibition of protein synthesis through inhibition of phenylalanyl-tRNA synthetase, (2) mitochondrial dysfunctions and the production of reactive oxygen and nitrogen species (ROS and RNS) and lipid peroxidation, (3) inhibition of histone acetyltransferase, which leads to disruption of mitosis and chromosomal instability as well as, (4) DNA adducts, particularly deoxyguanosine (dG) adducts (Fink-Gremmels et al. 1995; Mally 2012; Omar et al. 1990; Pfohl-Leszkowicz and Manderville 2012; Sorrenti et al. 2013). Although the kidney is generally believed to be the main target organ for OTA toxicity, its well-known inhibition of cellular protein synthesis and the generation of reactive oxygen as well as nitrogen species

Table 2 Modulation of the intestinal barrier function by zearalenone

\begin{tabular}{llll}
\hline Model & Concentration and exposure time & Effects on barrier function & References \\
\hline Zearalenone & & & \\
IPEC-1 cells & $25-50 \mu \mathrm{M}$ & ZEA: no effect on TEER values & Marin et al. (2015) \\
& 10 days & $\alpha-Z O L$ and $\beta-Z O L:$ decrease in TEER values & Liu et al. (2014) \\
Rat & $0.3-146 \mathrm{mg} / \mathrm{kg}$ bw & ZEA: decrease in transcript level of CLDN4 and OCLN in jejunum & \\
& 7 days & & \\
\hline
\end{tabular}


suggest that the liver and the GI tract may be a possible target organ for OTA as well (Bouhet and Oswald 2005; Grenier and Applegate 2013).

\section{Effects of ochratoxin A on intestinal barrier function}

Modulation of the intestinal barrier by OTA has mainly been studied using the in vitro Caco-2 cell model (Table 3 ). For the first time, Maresca et al. (2001) showed that the OTA exposure results in a concentration- and time-dependent decrease in TEER values of both Caco-2 and HT-29-D4 cells. They showed that the apical surface is more susceptible to OTA in comparison with exposure via the basolateral surface; in contrast, other studies reported that both apical and basolateral surfaces are equally affected by OTA (Maresca et al. 2001; McLaughlin et al. 2004). Ranaldi et al. (Ranaldi et al. 2007) found that the TEER decrease in OTA-exposed Caco- 2 cells at concentrations up to $200 \mu \mathrm{M}$ for $48 \mathrm{~h}$ is reversible and a full recovery of TEER value is achieved within $24 \mathrm{~h}$ after cessation of mycotoxin exposure. It has been reported that the OTA-induced TEER decrease is accompanied with an increase in the translocation of paracellular markers, such as 4, $10 \mathrm{kDa}$ FITC-dextran and horseradish peroxidase (HRP, $44 \mathrm{kDa}$ ) (Table 3). The OTA-induced permeability is shown to be size selective, since translocation of 20 and $40 \mathrm{kDa}$ FITC-dextran remains unchanged after exposure of Caco-2 cells to OTA up to $100 \mu \mathrm{M}$ for $24 \mathrm{~h}$ (Maresca et al. 2008; McLaughlin et al. 2004). OTA-induced intestinal permeability is associated with specific alterations in the expression (at transcriptional and protein levels) as well as distribution of different TJs. A down-regulation in mRNA expression levels of CLDN3, CLDN4 and OCLN was observed in OTA-exposed Caco-2 cells (Romero et al. 2016). CLDN3 and CLDN4 have been reported to be the most susceptible TJ proteins regarding OTA exposure to human intestinal epithelial cells (Lambert et al. 2007; McLaughlin et al. 2004; Ranaldi et al. 2007; Romero et al. 2016). Of clinical relevance is the finding that the OTA-induced intestinal barrier impairment in concentrations equal or higher than $1 \mu \mathrm{M}$ OTA triggers a concentration- and time-dependent increase in the translocation of Escherichia coli across Caco-2 cell monolayers (Maresca et al. 2008).

\section{Patulin}

Patulin (PAT) is a mycotoxin produced by various species of Penicillium, Aspergillus and Byssochylamys, known as fruit-spoiling fungi (Marin et al. 2013; Moake et al. 2005). Based on experimental models in mice, PAT was initially suspected to increase the prevalence of gastric cancers, but the IARC has classified PAT as a group 3 carcinogen (not carcinogenic to humans) due to inadequate evidence for the carcinogenicity of PAT in both experimental animals and humans (IARC 1987). Currently, the GI tract and the immune system are thought to be the most affected tissues following PAT exposure (Maresca and Fantini 2010; Moake et al. 2005). PAT is believed to induce cytotoxicity by forming covalent adducts with essential cellular thiols (organic compounds that contain a sulfhydryl group), by which it inhibits the activity of many enzymes. One of the most likely cellular targets of PAT is the sulfhydryl group of cysteine (Cys) and glutathione (GSH) leading to depletion of glutathione and subsequent increased generation of ROS (Fliege and Metzler 2000; Marin et al. 2013; Pfenning et al. 2014; Puel et al. 2010; Schebb et al. 2009). A recent

Table 3 Modulation of the intestinal barrier function by ochratoxin A

\begin{tabular}{|c|c|c|c|}
\hline Model & $\begin{array}{l}\text { Concentration and exposure } \\
\text { time }\end{array}$ & Effects on barrier function & References \\
\hline \multicolumn{4}{|l|}{ Ochratoxin A } \\
\hline Caco- 2 cells & $\begin{array}{l}100 \mu \mathrm{M} \\
24 \mathrm{~h}\end{array}$ & $\begin{array}{l}\text { Decrease in TEER values } \\
\text { Increase in permeability of } 4 \text { and } 10 \mathrm{kDa} \text { FITC-dextran } \\
\text { Decrease in protein expression of CLDN3 and CLDN4 }\end{array}$ & McLaughlin et al. (2004) \\
\hline Caco- 2 cells & $\begin{array}{l}1-100 \mu \mathrm{M} \\
12 \mathrm{~h}\end{array}$ & $\begin{array}{l}\text { Decrease in TEER values } \\
\text { Increase in permeability of HRP and } 4 \mathrm{kDa} \text { FITC-dextran } \\
\text { Increase in translocation of commensal Escherichia coli (strain k12) }\end{array}$ & Maresca et al. (2008) \\
\hline Caco- 2 cells & $\begin{array}{l}100 \mu \mathrm{M} \\
24 \mathrm{~h}\end{array}$ & $\begin{array}{l}\text { Decrease in TEER values } \\
\text { Decrease in protein expression of CLDN3 and CLDN4 }\end{array}$ & Lambert et al. (2007) \\
\hline Caco- 2 cells & $\begin{array}{l}40-1000 \mu \mathrm{M} \\
48 \mathrm{~h}\end{array}$ & $\begin{array}{l}\text { Decrease in TEER values } \\
\text { Affect the distribution pattern of CLDN4 }\end{array}$ & Ranaldi et al. (2007) \\
\hline Caco- 2 cells & $\begin{array}{l}10 \mu \mathrm{M} \\
3 \mathrm{~h}\end{array}$ & $\begin{array}{l}\text { Neither a significant decrease in TEER values nor an increase in } \\
\text { permeability of }\left[{ }^{14} \mathrm{C}\right] \text {-mannitol }\end{array}$ & Sergent et al. (2005) \\
\hline Caco- 2 cells & $\begin{array}{l}1-100 \mu \mathrm{M} \\
7 \text { days }\end{array}$ & $\begin{array}{l}\text { Decrease in TEER values } \\
\text { Decrease in transcript level of CLDN3, CLDN4 and OCLN }\end{array}$ & Romero et al. (2016) \\
\hline $\begin{array}{l}\text { Caco-2 cells } \\
\text { HT-29-D4 cells }\end{array}$ & $\begin{array}{l}00.1-100 \mu \mathrm{M} \\
48 \mathrm{~h}\end{array}$ & Decrease in TEER values & Maresca et al. (2001) \\
\hline
\end{tabular}


study conducted by Boussabbeh et al. (Boussabbeh et al. 2015) revealed that PAT induces apoptosis through the ROS-mediated endoplasmic reticulum stress pathway.

\section{Effects of patulin on intestinal barrier function}

Impairment of intestinal barrier integrity induced by PAT has been clearly shown in different studies (Table 4). PAT is found to induce a rapid and dramatic decrease in TEER values of Caco-2 and HT-29-D4 monolayers (Assuncao et al. 2014, 2016; Mahfoud et al. 2002; McLaughlin et al. 2009). PAT exposure to either apical or basolateral surface resulted in a concentration- and time-dependent decrease in TEER levels. The apical surface seems to be slightly more sensitive than the basolateral surface (Mahfoud et al. 2002; McLaughlin et al. 2009). Mohan et al. (2012) showed that PAT at concentrations equal or higher than $1.6 \mu \mathrm{M}$ causes an increase in plasma membrane permeability, observed by increased TOTO-3 fluorescence intensity. In addition, it has been reported that PAT induces the permeability of different paracellular markers such as HRP and FITC-dextrans of 4-40 kDa across the intestinal epithelium (Table 4) (Katsuyama et al. 2014; Maresca et al. 2008; McLaughlin et al.
2009). Maresca et al. (2008) showed that the impairment of intestinal integrity by PAT results in an increased translocation of $E$. coli across Caco- 2 cell monolayers. There are different studies demonstrating specific effects of PAT on TJs. For example, it is shown that 5-h exposure of Caco-2 cell monolayers to $100 \mu \mathrm{M}$ PAT leads to proteolytic cleavage of OCLN and a significant reduction in ZO-1 protein levels. However, the expression levels of CLDN1, CLDN3 and CLDN4 were not changed (McLaughlin et al. 2009). Kawauchiya et al. (2011) demonstrated that the exposure of Caco- 2 cells to $50 \mu \mathrm{M}$ PAT resulted in a gradual decrease in protein expression of ZO-1, while the expression levels of CLDN4 and OCLN remained unaffected up to $72 \mathrm{~h}$. Interestingly, the decreased ZO-1 expression observed in latter study was correlated with an increased phosphorylation of this protein, while phosphorylation of CLDN4 and OCLN was not detected. This is in contrast to the finding of Katsuyama et al. (2014) who reported an increase in phosphorylation of CLDN4 following a 24-h exposure of Caco-2 cells to PAT at a concentration of $50 \mu \mathrm{M}$. PAT also affects the distribution pattern of different TJs including CLDN1, CLDN3, CLDN4, OCLN and ZO-1 (Katsuyama et al. 2014; Kawauchiya et al. 2011; McLaughlin et al. 2009).

Table 4 Modulation of the intestinal barrier function by patulin

\begin{tabular}{|c|c|c|c|}
\hline Model & $\begin{array}{l}\text { Concentration and exposure } \\
\text { time }\end{array}$ & Effects on barrier function & References \\
\hline \multicolumn{4}{|l|}{ Patulin } \\
\hline Caco- 2 cells & $\begin{array}{l}100 \mu \mathrm{M} \\
5 \mathrm{~h}\end{array}$ & $\begin{array}{l}\text { Decrease in TEER values } \\
\text { Increase in permeability of } 4,10,20 \text { and } 40 \mathrm{kDa} \text { FITC-dextran } \\
\text { Proteolysis of OCLN } \\
\text { Decrease in protein expression of ZO-1 } \\
\text { Affect the distribution pattern of CLDN1, CLDN3, CLDN4, } \\
\text { OCLN and ZO-1 }\end{array}$ & McLaughlin et al. (2009) \\
\hline Caco- 2 cells & $\begin{array}{l}50 \mu \mathrm{M} \\
72 \mathrm{~h}\end{array}$ & $\begin{array}{l}\text { Decrease in TEER values } \\
\text { Decrease in protein expression of ZO-1 } \\
\text { Increase in phosphorylation of ZO-1 } \\
\text { Affect the distribution pattern of CLDN4, OCLN and ZO-1 }\end{array}$ & Kawauchiya et al. (2011) \\
\hline Caco- 2 cells & $\begin{array}{l}50 \mu \mathrm{M} \\
36 \mathrm{~h}\end{array}$ & $\begin{array}{l}\text { Decrease in TEER values } \\
\text { Increase in permeability of } 4 \mathrm{kDa} \text { FITC-dextran } \\
\text { Increase in phosphorylation of CLDN } 4 \\
\text { Affect the distribution pattern of ZO-1 }\end{array}$ & Katsuyama et al. (2014) \\
\hline Caco- 2 cells & $\begin{array}{l}1-100 \mu \mathrm{M} \\
12 \mathrm{~h}\end{array}$ & $\begin{array}{l}\text { Decrease in TEER values } \\
\text { Increase in permeability of HRP and } 4 \mathrm{kDa} \text { FITC-dextran } \\
\text { Increase in translocation of commensal Escherichia coli (strain } \\
\mathrm{k} 12 \text { ) }\end{array}$ & Maresca et al. (2008) \\
\hline Caco- 2 cells & $\begin{array}{l}0.2-100 \mu \mathrm{M} \\
72 \mathrm{~h}\end{array}$ & Increase in plasma membrane permeability & Mohan et al. (2012) \\
\hline Caco- 2 cells & $\begin{array}{l}25 \mathrm{nM}-95 \mu \mathrm{M} \\
24 \mathrm{~h}\end{array}$ & Decrease in TEER values & Assuncao et al. (2014) \\
\hline Caco- 2 cells & $\begin{array}{l}50 \mu \mathrm{M} \\
24 \mathrm{~h}\end{array}$ & $\begin{array}{l}\text { Decrease in TEER values } \\
\text { Decrease in protein expression of } \mathrm{ZO}-1\end{array}$ & Assuncao et al. (2016) \\
\hline $\begin{array}{l}\text { Caco-2 cells } \\
\text { HT-29-D4 cells }\end{array}$ & $\begin{array}{l}1-100 \mu \mathrm{M} \\
24 \mathrm{~h}\end{array}$ & Decrease in TEER values & Mahfoud et al. (2002) \\
\hline Rat colonic explants & $\begin{array}{l}100-500 \mu \mathrm{M} \\
2 \mathrm{~h}\end{array}$ & $\begin{array}{l}\text { Decrease in TEER values } \\
\text { Increase in permeability of }\left[{ }^{14} \mathrm{C}\right] \text {-mannitol }\end{array}$ & Mohan et al. (2012) \\
\hline
\end{tabular}


Moreover, PAT exposed to isolated rat colonic mucosa at a concentration of $500 \mu \mathrm{M}$ for $2 \mathrm{~h}$ has been shown to induce intestinal barrier breakdown demonstrated by a decrease in TEER values and an increase in $\left[{ }^{14} \mathrm{C}\right]$-mannitol (182 Da) permeability (Mohan et al. 2012). There are a few possible mechanisms underlying the PAT-induced impairment of TJs and intestinal barrier function. For example, Mahfoud et al. (2002) showed that the PAT-induced TEER decrease involves inhibition of protein tyrosine phosphatase (PTP) through inactivation of cysteine residues in the catalytic domains of PTP. The high affinity of PAT for sulfhydryl groups of Cys and GSH (explained above) may account for the barrier impairment, since addition of $1.6 \mathrm{mM} \mathrm{GSH}$ was found to completely prevent PAT-induced TEER drop. Therefore, higher amount of GSH in Caco-2 cells compared to HT-29-D4 cells ( 8.0 vs. $4.5 \mathrm{nmol} / \mathrm{mg}$ of protein) may explain the different sensitivity of these cells to PAT (Mahfoud et al. 2002). It has been recently suggested that PAT decreases the expression of density-enhanced phosphatase-1 (DEP-1) through down-regulation of proliferator-activated receptor gamma (PPAR $\gamma$ ) (Katsuyama et al. 2014). DEP-1 is a class III transmembrane phophatidylinositol-phosphate, which has been proposed to regulate different signal transduction pathways, such as cell migration, proliferation, differentiation and adhesion (Balavenkatraman et al. 2006; Petermann et al. 2011). Furthermore, it has been observed that a PAT-mediated decrease in DEP-1 results in hyperphosphorylation of CLDN4 and subsequently hinders the interaction between ZO-1 and CLDN4, which leads to release of CLDN4 from the TJ network (Katsuyama et al. 2014). In addition, McLaughlin et al. (McLaughlin et al. 2009) speculated that matrix metalloproteinases (MMPs) may play a role, at least partly, in the observed intestinal barrier impairment induced by PAT, since inhibition of MMP partially protected OCLN from PAT-mediated cleavage. However, according to their findings, the reduction in ZO-1 levels is not prevented by MMP inhibitors.

\section{Fumonisin $\mathbf{B}_{1}$}

Fumonisin $\mathrm{B}_{1}\left(\mathrm{FB}_{1}\right)$ is the major representative of structurally related fumonisins produced by various specious of Fusarium, predominantly by Fusarium verticillioidis. Initially, $\mathrm{FB}_{1}$ has been associated with an increased prevalence of esophageal cancers in humans in the Transkei region of South Africa (Chu and Li 1994; Rheder et al. 1992; Sydenham et al. 1990). IARC has classified $\mathrm{FB}_{1}$ as a group $2 \mathrm{~B}$ carcinogen (possibly carcinogenic to humans) (IARC 2002). Maternal exposure to fumonisins increases the risk of neural tube defects (such as spina bifida and anencephaly) in offspring, mainly through interference with the function of folate-binding protein and the utilization of folic acid (Gelineau-van Waes et al. 2005; Marasas et al. 2004; Missmer et al. 2006; Sadler et al. 2002). FB 1 has been shown to be hepatotoxic, nephrotoxic, carcinogenic and immunotoxic in various animal species (Voss et al. 2007). The main mechanism of action is inhibition of the enzyme ceramide synthase (CerS) (Enongene et al. 2000; Loiseau et al. 2007, 2015; Voss et al. 2007). CerS is a key enzyme that catalyzes the formation of complex sphingolipids from the sphingoid bases (Mullen et al. 2012; Voss et al. 2007). $\mathrm{FB}_{1}$ is observed to inhibit mainly CerS4 isomers (CerS1 and CerS2 isomers are also inhibited to a lesser extent) and leads to the accumulation of sphingoid bases (including sphinganine and sphingosine) and in turn to a depletion of ceramide and complex sphingolipids (Enongene et al. 2000; Loiseau et al. 2007, 2015; Marin et al. 2013; Voss et al. 2007). It is well known that sphingolipids participate in a variety of cellular signaling pathways, such as regulation of cell proliferation, differentiation and apoptosis (Mullen et al. 2012; Ribeiro et al. 2010). Although liver and kidney are thought to be the most affected tissues by $\mathrm{FB}_{1}$ in animal species, the GI tract has also been reported as a possible target organ for $\mathrm{FB}_{1}$ (Bouhet and Oswald 2007; Voss et al. 2007). It has been shown that a single subcutaneous injection of $\mathrm{FB}_{1}$ ( $25 \mathrm{mg} / \mathrm{kg}$ body weight (bw)) causes a transient increase in sphinganine and sphingosine in the mouse small intestine over $24 \mathrm{~h}$ (Enongene et al. 2000). Exposure of pigs to $\mathrm{FB}_{1}(1.5 \mathrm{mg} / \mathrm{kg} \mathrm{bw})$ for 7 days results in a significant increase in the concentration of sphinganine and sphingosine and a decrease in the total glycolipid content as well as alteration in the jejunal glycolipid composition, whereas no changes are observed in the duodenum and ileum (Loiseau et al. 2007).

\section{Effects of fumonisin $B_{1}$ on intestinal barrier function}

Impairment of the intestinal barrier integrity induced by $\mathrm{FB}_{1}$ has been shown in different in vitro, ex vivo and in vivo studies (Table 5). A concentration- and time-dependent decrease in TEER values of Caco- 2 and IPEC- 1 cells (intestinal porcine epithelial cells) have been observed after $\mathrm{FB}_{1}$ exposure; however, this process in IPEC-1 cells was time dependent as significant effects occurred only after longterm exposure (Bouhet et al. 2004; Loiseau et al. 2007; Romero et al. 2016). Bouhet et al. (2004) demonstrated that $\mathrm{FB}_{1}$-induced decrease in TEER values is independent from the differentiation stage of IPEC- 1 cells and this TEER drop is partially reversible. Another study has shown that the impaired intestinal barrier results in an increase in permeability for $\mathrm{FB}_{1}$ across the IPEC-1 cells, suggesting that after long-term exposure, the very low absorption rate (normally $\sim 3 \%$ ) may increase over time (Loiseau et al. 2007). Surprisingly, an increase in TEER values of porcine jejunal explants is reported after 2 -h exposure to $\mathrm{FB}_{1}$ at 
Table 5 Modulation of the intestinal barrier function by fumonisin $B_{1}$

\begin{tabular}{|c|c|c|c|}
\hline Model & $\begin{array}{l}\text { Concentration and exposure } \\
\text { time }\end{array}$ & Effects on barrier function & References \\
\hline \multicolumn{4}{|l|}{ Fumonisin $B_{1}$} \\
\hline Caco-2 cells & $\begin{array}{l}1-100 \mu \mathrm{M} \\
7 \text { days }\end{array}$ & $\begin{array}{l}\text { Decrease in TEER values } \\
\text { Decrease in transcript level of CLDN3, CLDN4 and OCLN }\end{array}$ & Romero et al. (2016) \\
\hline IPEC -1 cells & $\begin{array}{l}50-200 \mu \mathrm{M} \\
16 \text { days }\end{array}$ & $\begin{array}{l}\text { Decrease in TEER values } \\
\text { Increase in permeability of } \mathrm{FB}_{1}\end{array}$ & Loiseau et al. (2007) \\
\hline IPEC- 1 cells & $\begin{array}{l}20-200 \mu \mathrm{M} \\
4 \mathrm{~h}\end{array}$ & $\begin{array}{l}\text { Increase in translocation of pathogenic Escherichia coli } \\
\text { (strain 28C) }\end{array}$ & Bouhet and Oswald (2007) \\
\hline IPEC -1 cells & $\begin{array}{l}50-500 \mu \mathrm{M} \\
28 \text { days }\end{array}$ & Decrease in TEER values & Bouhet et al. (2004) \\
\hline Porcine jejunal explants & $\begin{array}{l}10 \mu \mathrm{M} \\
2 \mathrm{~h}\end{array}$ & $\begin{array}{l}\text { Increase in TEER values } \\
\text { Increase in permeability of HRP }\end{array}$ & Lalles et al. (2009) \\
\hline Piglet & $\begin{array}{l}3 \mathrm{mg} / \mathrm{kg} \text { feed } \\
5 \text { weeks }\end{array}$ & Decrease in protein expression of OCLN in ileum & Bracarense et al. (2012) \\
\hline Piglet & $\begin{array}{l}0.5 \mathrm{mg} / \mathrm{kg} \text { bw } \\
7 \text { days }\end{array}$ & $\begin{array}{l}\text { Increase in translocation of pathogenic Escherichia coli } \\
\left(\text { strain } 28 \mathrm{CNal}^{\mathrm{r}}\right)\end{array}$ & Oswald et al. (2003) \\
\hline
\end{tabular}

concentration of $10 \mu \mathrm{M}$. In contrast, a significant increase in HRP permeability is reported following treatment with $10 \mu \mathrm{M} \mathrm{FB}{ }_{1}$ over the same time period (Lalles et al. 2009). In vitro and in vivo studies have showed that $\mathrm{FB}_{1}$-induced barrier function impairment causes an increase in the translocation of pathogenic $E$. coli across intestinal epithelial cells (Bouhet and Oswald 2007; Oswald et al. 2003). Furthermore, $E$. coli could be recovered from lung and mesenteric lymph nodes 7 days after oral exposure of pigs to $\mathrm{FB}_{1}$ at a dose of $0.5 \mathrm{mg} / \mathrm{kg}$ bw (Oswald et al. 2003). The $\mathrm{FB}_{1}$ induced barrier impairment in Caco- 2 cells has been shown to be accompanied with a significant decrease in the transcript level of CLDN3, CLDN4 and OCLN (Romero et al. 2016). Bracarense et al. (Bracarense et al. 2012) observed that the exposure of piglets to a $\mathrm{FB}_{1}$-contaminated diet ( $3 \mathrm{mg} / \mathrm{kg}$ ) for 5 weeks significantly decreases the protein expression of OCLN in ileum. Further studies would be needed to clarify the involvement of TJ impairment in $\mathrm{FB}_{1}$ induced impairment of the intestinal integrity.

\section{Trichothecenes}

The class of trichothecenes comprises a unique family of over 200 tetracyclic sesquiterpenoid fungal metabolites produced by various species of the genera Fusarium, Stachybotrys, Cephalosporium, Myrothecium, Spicellum, Verticimonosporium, Trichoderma and Trichothecium (McCormick et al. 2011; Rocha et al. 2005; Wu et al. 2013). Common structure elements of trichothecenes are a C-9, C-10 double bond and $\mathrm{C}-12, \mathrm{C}-13$ epoxide moiety contributing to the toxicity of trichothecenes (Escriva et al. 2015; McCormick et al. 2011; Sudakin 2003). Trichothecenes are classified into four different types (type A-D) according to the characteristic functional group. Type A trichothecenes are characterized by a hydroxyl motif at C-8 (e.g., T-2/HT-2 toxins), whereas type $\mathrm{B}$ trichothecenes carry a keto (carbonyl) motif at this position (e.g., nivalenol, deoxynivalenol). Type $\mathrm{C}$ trichothecenes have an additional epoxide group at the $\mathrm{C}-7, \mathrm{C}-8$ or $\mathrm{C}-9, \mathrm{C}-10$ position (e.g., crotocin), while type $\mathrm{D}$ trichothecenes possess a macrocyclic ring between the C-4, C-15 positions (e.g., roridin) (McCormick et al. 2011; Rocha et al. 2005; Shank et al. 2011; Sudakin 2003; Wu et al. 2013). Among them, type A and type B are known to be the most prevalent trichothecenes (Nathanail et al. 2015; Wu et al. 2013). At the cellular level, type A and type B trichothecenes not only interact with the peptidyl transferase at the $60 \mathrm{~S}$ ribosomal subunit to cause a translational arrest and protein synthesis inhibition, but also activate intracellular protein kinases, particularly mitogenactivated protein kinases (MAPKs) and their downstream effectors resulting in a process, known as ribotoxic stress response (Rocha et al. 2005; Shank et al. 2011; Wu et al. 2013, 2014b). Rapidly dividing cells, particularly intestinal epithelial cells and immune cells, are generally believed to be the major target organs for type A and type B trichothecenes (Li et al. 2011; Pinton et al. 2012). In consideration of the complex group of trichothecenes and the availability of detailed investigations, only major representatives of this class of mycotoxins such as T-2/HT-2 toxin, nivalenol (NIV) and deoxynivalenol (DON) will be discussed in more detail below. Their effects on intestinal barrier integrity are summarized in Table 6 at the end of this chapter.

\section{T-2/HT-2 toxin}

Historically, prolonged exposure of humans to T-2 toxin has been associated with a disease known as alimentary 
toxic aleukia (ATA); characterized by nausea, vomiting, diarrhea, gastroenteritis, leukopenia (aleukia), hemorrhages, skin inflammation and in severe cases a death due to asphyxia (Joffe 1971). Genotoxicity and mutagenicity of T-2 are still a matter of controversial debate, and IARC has classified T-2 toxin as a group 3 carcinogen (not carcinogenic to humans) due to inadequate evidence for the carcinogenicity in both experimental animals and humans (IARC 1993). The major mechanisms of toxicity of T-2 toxin are described as I) inhibition of protein synthesis (at the initiation step of protein translation) through interaction with the peptidyl transferase at the $60 \mathrm{~S}$ ribosomal subunit and II) generation of ROS and oxidative stress leading to caspase-mediated cellular apoptosis (Chaudhari et al. 2009; Rocha et al. 2005; Wu et al. 2013, 2014b). Rapidly after ingestion, T-2 toxin is mainly metabolized into HT-2 toxin, through a deacetylation reaction by intestinal microflora, and various hydroxylated metabolites in the liver. The toxicity of HT-2 is quite similar to that of the T-2 toxin, and their effects cannot be differentiated. However, it has been speculated that HT-2 toxin is responsible for the observed in vivo toxicity following T-2 toxin ingestion (Escriva et al. 2015; Li et al. 2011; Wu et al. 2013).

\section{Effects of T-2/HT-2 toxin on intestinal barrier function}

Despite the well-documented clinical and pathological intestinal lesions induced by T-2 toxin (Pinton et al. 2012), the effects of T-2 toxin on intestinal integrity have hardly been studied (Table 6). However, a study conducted by Goossens et al. (2012) clearly showed that T-2 toxin causes an impairment of the barrier function at a concentration of $21 \mathrm{nM}$ as observed by a decrease in TEER values and an increase in the passage of the antibiotics doxycycline and paromomycin across IPEC-J2 cells (intestinal porcine epithelial cells). Another study reported that the exposure of mice to $\mathrm{T}-2$ toxin $(3.3 \mathrm{mg} / \mathrm{kg} \mathrm{bw})$ for 20 days results in an increased translocation of Mycobacterium tuberculosis (Kanai and Kondo 1984). In addition, a significant increase in the translocation of Salmonella typhimurium across IPEC-J2 cell monolayer occurs already $30 \mathrm{~min}$ after T-2 toxin exposure with concentrations as low as $2.1 \mathrm{nM}$ (Verbrugghe et al. 2012). Surprisingly in the same study, TEER values remained unaffected up to $24 \mathrm{~h}$ after exposure to concentrations of T-2 toxin ranging from 1.6 to $10.7 \mathrm{nM}$ (Verbrugghe et al. 2012). It has recently been reported that the TEER decrease in T-2 toxin-exposed Caco- 2 cells at concentrations up to $100 \mu \mathrm{M}$ for 7 days is accompanied with a significant decrease in the transcript level of CLDN3, CLDN4 and OCLN (Romero et al. 2016). The exact mechanisms underlying the gut barrier dysfunction induced by T-2/HT-2 toxin are unknown and would require further investigations.

\section{Nivalenol}

Nivalenol (NIV) is one of the less studied type B trichothecenes, and little is known about the toxicity of NIV in humans (EFSA 2013). Some studies suggest that exposure to dietary NIV could be associated with an increased incidence of esophageal and gastric cancers in certain regions of China (EFSA 2013; Escriva et al. 2015; Hsia et al. 2004). However, IARC has classified NIV as a group 3 carcinogen (not carcinogenic to humans) due to inadequate evidence for the carcinogenicity in both experimental animals and humans (IARC 1993). NIV is usually found together with DON, and synergistic interactions between them are assumed (Alassane-Kpembi et al. 2013). DON and NIV share highly similar chemical structures, and the only difference between them is a single oxygen atom at the $\mathrm{C}-4$ position in the trichothecene structure (hydrogen and hydroxyl group at the C-4 position in DON and NIV, respectively) (Escriva et al. 2015; Shank et al. 2011; Wu et al. 2013). Although less prevalent in food commodities, NIV is generally believed to have a higher toxicity than DON (Bianco et al. 2012; Cheat et al. 2015; Pinton and Oswald 2014). Unlike DON, NIV inhibits protein synthesis by inhibiting the initiation step of protein translation through interaction with peptidyl transferase at the 60S ribosomal subunit (Rocha et al. 2005). Using different approaches, the effects of NIV on intestinal epithelial cells have been acknowledged. Recently, it has been reported that NIV induces oxidative stress in IEC-6 cells (non-tumorigenic rat intestinal epithelial cell line) by generation of ROS and inducible nitric oxide synthase (iNOS), which leads to activation of nuclear factor kappa B (NF- $\mathrm{KB}$ ) and nuclear factor erythroid 2-related factor 2 (Nrf2) pathways (Del Regno et al. 2015). A study conducted by Bianco et al. (2012) showed that NIV induces apoptosis in IEC-6 cells by inhibition of the anti-apoptotic protein B cell lymphoma-2 (BCL-2) and the induction of the pro-apoptotic protein $\mathrm{Bcl}-2$-associated $\mathrm{X}$ protein (BAX) as well as caspase-3 activation. Induction of apoptosis was further confirmed in ex vivo pig jejunal explant and in vivo pig intestinal loops (Cheat et al. 2015). However, the effect of NIV on the intestinal barrier function has not been studied yet.

\section{Deoxynivalenol and its mono-acetylated derivatives}

Deoxynivalenol (DON) is believed to be the most widely distributed trichothecene (Escriva et al. 2015; Pestka $2010 \mathrm{~b}$ ). The high incidence of human exposure is confirmed by the analysis of urine samples for DON and its glucuronides, demonstrating that the exposure incidence exceeds $90 \%$ of the tested population in many cases (Hepworth et al. 2012; Sarkanj et al. 2013; Turner et al. 2011; Wang et al. 2014; Warth et al. 2012). Human exposure to 
Table 6 Modulation of the intestinal barrier function by trichothecenes

\begin{tabular}{|c|c|c|c|}
\hline Model & $\begin{array}{l}\text { Concentration and exposure } \\
\text { time }\end{array}$ & Effects on barrier function & References \\
\hline \multicolumn{4}{|l|}{ T-2 toxin } \\
\hline Caco-2 cells & $\begin{array}{l}1-100 \mu \mathrm{M} \\
7 \text { days }\end{array}$ & $\begin{array}{l}\text { Decrease in TEER values } \\
\text { Decrease in transcript level of CLDN3, CLDN4 and } \\
\text { OCLN }\end{array}$ & Romero et al. (2016) \\
\hline IPEC-J2 cells & $\begin{array}{l}0.21-210 \mathrm{nM} \\
72 \mathrm{~h}\end{array}$ & $\begin{array}{l}\text { Decrease in TEER values } \\
\text { Increase in permeability of doxycycline and paromo- } \\
\text { mycin }\end{array}$ & Goossens et al. (2012) \\
\hline IPEC-J2 cells & $\begin{array}{l}1.6-10.7 \mathrm{nM} \\
1 \mathrm{~h}\end{array}$ & $\begin{array}{l}\text { Increase in translocation of Salmonella typhimurium } \\
\text { (strain 112910a) }\end{array}$ & Verbrugghe et al. (2012 \\
\hline Mouse & $\begin{array}{l}3.3 \mathrm{mg} / \mathrm{kg} \text { bw } \\
20 \text { days }\end{array}$ & $\begin{array}{l}\text { Increase in translocation of Mycobacterium tuberculo- } \\
\text { sis (strain H37RvR-KM) }\end{array}$ & Kanai and Kondo (198 \\
\hline \multicolumn{4}{|l|}{ Deoxynivalenol } \\
\hline Caco- 2 cells & $\begin{array}{l}1.39-12.5 \mu \mathrm{M} \\
24 \mathrm{~h}\end{array}$ & $\begin{array}{l}\text { Decrease in TEER values } \\
\text { Decrease in horizontal impedance value } \\
\text { Increase in permeability of LY and } 4 \text { kDa FITC- } \\
\text { dextran } \\
\text { Increase in transcript level of CLDN3, CLDN4, } \\
\text { OCLN and ZO-1 } \\
\text { Decrease in protein expression of CLDN1, CLDN3 } \\
\text { and CLDN4 } \\
\text { Affect the distribution pattern of CLDN1, CLDN3, } \\
\text { CLDN4, OCLN and ZO-1 }\end{array}$ & Akbari et al. (2014) \\
\hline Caco- 2 cells & $\begin{array}{l}0.16-16 \mu \mathrm{M} \\
24 \mathrm{~h}\end{array}$ & $\begin{array}{l}\text { Decrease in TEER values } \\
\text { Increase in permeability of mannitol } \\
\text { Increase in transcript level of CLDN4 and OCLN } \\
\text { Decrease in protein expression of CLDN4 }\end{array}$ & De Walle et al. (2010) \\
\hline Caco- 2 cells & $\begin{array}{l}5-100 \mu \mathrm{M} \\
48 \mathrm{~h}\end{array}$ & $\begin{array}{l}\text { Decrease in TEER values } \\
\text { Increase in permeability of } 4 \mathrm{kDa} \text { FITC-dextran } \\
\text { Increase in translocation of pathogenic Escherichia } \\
\text { coli (strain 28C) } \\
\text { Decrease in protein expression of CLDN4 }\end{array}$ & Pinton et al. (2009) \\
\hline Caco- 2 cells & $\begin{array}{l}1-100 \mu \mathrm{M} \\
12 \mathrm{~h}\end{array}$ & $\begin{array}{l}\text { Decrease in TEER values } \\
\text { Increase in permeability of HRP and } 4 \mathrm{kDa} \text { FITC- } \\
\text { dextran } \\
\text { Increase in translocation of commensal Escherichia } \\
\quad \text { coli (strain k12) }\end{array}$ & Maresca et al. (2008) \\
\hline Caco- 2 cells & $\begin{array}{l}0.37-1.5 \mu \mathrm{M} \\
6-120 \mathrm{~h}\end{array}$ & $\begin{array}{l}\text { Decrease in horizontal impedance value of undifferen- } \\
\text { tiated cells }\end{array}$ & Manda et al. (2015) \\
\hline $\begin{array}{l}\text { Caco- } 2 \text { cells } \\
\text { T84 cells }\end{array}$ & $\begin{array}{l}0.16-0.67 \mu \mathrm{M} \\
14 \text { days }\end{array}$ & $\begin{array}{l}\text { Decrease in TEER values } \\
\text { Increase in permeability of LY }\end{array}$ & Kasuga et al. (1998) \\
\hline HT-29-D4 cells & $\begin{array}{l}0.001-100 \mu \mathrm{M} \\
48 \mathrm{~h}\end{array}$ & Decrease in TEER values & Maresca et al. (2002) \\
\hline IPEC- 1 cells & $\begin{array}{l}30 \mu \mathrm{M} \\
48 \mathrm{~h}\end{array}$ & $\begin{array}{l}\text { Decrease in TEER values } \\
\text { Increase in permeability of } 4 \mathrm{kDa} \text { FITC-dextran } \\
\text { Decrease in protein expression of CLDN4 } \\
\text { Affect the distribution pattern of CLDN4 }\end{array}$ & Pinton et al. (2010) \\
\hline IPEC -1 cells & $\begin{array}{l}5-50 \mu \mathrm{M} \\
48 \mathrm{~h}\end{array}$ & $\begin{array}{l}\text { Decrease in TEER values } \\
\text { Increase in permeability of } 4 \mathrm{kDa} \text { FITC-dextran } \\
\text { Decrease in protein expression of CLDN3 and } \\
\text { CLDN4 }\end{array}$ & Pinton et al. (2009) \\
\hline $\begin{array}{l}\text { IPEC- } 1 \text { cells } \\
\text { IPEC-J } 2 \text { cells }\end{array}$ & $\begin{array}{l}0.67-6.7 \mu \mathrm{M} \\
48 \mathrm{~h}\end{array}$ & $\begin{array}{l}\text { Decrease in protein expression of } \mathrm{ZO}-1 \\
\text { Affect the distribution pattern of } \mathrm{ZO}-1\end{array}$ & Diesing et al. (2011b) \\
\hline IPEC-J2 cells & $\begin{array}{l}6.74 \mu \mathrm{M} \\
48 \mathrm{~h}\end{array}$ & $\begin{array}{l}\text { Decrease in TEER values } \\
\text { Decrease in protein expression of CLDN3, OCLN and } \\
\text { ZO-1 } \\
\text { Affect the distribution pattern of } \mathrm{ZO}-1\end{array}$ & Gu et al. (2014) \\
\hline
\end{tabular}


Table 6 continued

\begin{tabular}{|c|c|c|c|}
\hline Model & $\begin{array}{l}\text { Concentration and exposure } \\
\text { time }\end{array}$ & Effects on barrier function & References \\
\hline IPEC-J2 cells & $\begin{array}{l}0.67-13.4 \mu \mathrm{M} \\
24-72 \mathrm{~h}\end{array}$ & $\begin{array}{l}\text { Decrease in TEER values } \\
\text { Decrease in protein expression of CLDN3 and ZO-1 } \\
\text { Affect the distribution pattern of CLDN3 }\end{array}$ & Diesing et al. (2011a) \\
\hline IPEC-J2 cells & $\begin{array}{l}1.68-33.7 \mu \mathrm{M} \\
72 \mathrm{~h}\end{array}$ & $\begin{array}{l}\text { Decrease in TEER values } \\
\text { Increase in permeability of doxycycline and paromo- } \\
\text { mycin }\end{array}$ & Goossens et al. (2012) \\
\hline IPEC-J2 cells & $\begin{array}{l}0.33-3.3 \mu \mathrm{M} \\
24 \mathrm{~h}\end{array}$ & $\begin{array}{l}\text { Increase in translocation of pathogenic Salmonella } \\
\text { typhimurium (strain 112910a) }\end{array}$ & Vandenbroucke et al. (2011) \\
\hline IPEC-J2 cells & $\begin{array}{l}4 \mu \mathrm{M} \\
12 \mathrm{~h}\end{array}$ & $\begin{array}{l}\text { Decrease in TEER values } \\
\text { Increase in permeability of } 4 \mathrm{kDa} \text { FITC-dextran } \\
\text { Increase in translocation of commensal Escherichia } \\
\text { coli }\left(\text { strain ATCC }{ }^{\circledR} 25922^{\mathrm{TM}} \text { ) }\right. \\
\text { Increase in transcript level of CLDN1, CLDN4, } \\
\text { OCLN and ZO-1 } \\
\text { Decrease in protein expression of CLDN3 and } \\
\text { CLDN4 }\end{array}$ & Ling et al. (2016) \\
\hline Porcine jejunal explants & $\begin{array}{l}5-50 \mu \mathrm{M} \\
2 \mathrm{~h}\end{array}$ & Increase in permeability of $4 \mathrm{kDa}$ FITC-dextran & Pinton et al. (2009) \\
\hline Piglet & $\begin{array}{l}3 \mathrm{mg} / \mathrm{kg} \text { feed } \\
5 \text { weeks }\end{array}$ & Decrease in protein expression of OCLN in ileum & Bracarense et al. (2012) \\
\hline Pig & $\begin{array}{l}2.85 \mathrm{mg} / \mathrm{kg} \text { feed } \\
5 \text { weeks }\end{array}$ & Decrease in protein expression of CLDN4 in jejunum & Pinton et al. (2009) \\
\hline Pig & $\begin{array}{l}3.5 \mathrm{mg} / \mathrm{kg} \text { feed } \\
6 \text { weeks }\end{array}$ & $\begin{array}{l}\text { Decrease in transcript level of CLDN3, CLDN4 and } \\
\text { OCLN in ileum }\end{array}$ & Lessard et al. (2015) \\
\hline Pig & $\begin{array}{l}0.9 \mathrm{mg} / \mathrm{kg} \text { feed } \\
10 \text { days }\end{array}$ & $\begin{array}{l}\text { Increase in transcript level of CLDNs (cecum), OCLD } \\
\text { (duodenum, ileum, cecum and colon) and ZOs (duo- } \\
\text { denum and colon) } \\
\text { Decrease in transcript level of CLDN4, OCLN, ZO-1 } \\
\text { and ZO-2 in jejunum } \\
\text { Increase in protein expression of OCLN in duodenum, } \\
\text { jejunum and colon }\end{array}$ & Alizadeh et al. (2015) \\
\hline Mouse & $\begin{array}{l}25 \mathrm{mg} / \mathrm{kg} \text { bw } \\
6 \mathrm{~h}\end{array}$ & $\begin{array}{l}\text { Increase in permeability of } 4 \mathrm{kDa} \text { FITC-dextran } \\
\text { Increase in transcript level of CLDN2, CLDN3 and } \\
\text { CLDN4 in distal small intestine } \\
\text { Affect the distribution pattern of CLDN1-3 in distal } \\
\text { small intestine }\end{array}$ & Akbari et al. (2014) \\
\hline Mouse & $\begin{array}{l}5 \mathrm{mg} / \mathrm{kg} \text { bw } \\
24 \mathrm{~h}\end{array}$ & $\begin{array}{l}\text { Increase in transcript level of CLDN2 and CLDN3 in } \\
\text { duodenum } \\
\text { Decrease in protein expression of CLDN3 in duode- } \\
\text { num }\end{array}$ & Bol-Schoenmakers et al. (2016) \\
\hline Broiler chicken & $\begin{array}{l}7.5 \mathrm{mg} / \mathrm{kg} \text { feed } \\
3 \text { weeks }\end{array}$ & $\begin{array}{l}\text { Increase in transcript level of CLDN5 in jejunum and } \\
\text { CLDN1, CLDN5, ZO-1 and ZO-2 in ileum }\end{array}$ & Osselaere et al. (2013) \\
\hline \multicolumn{4}{|c|}{ 3-and 15-acetyl deoxynivalenol } \\
\hline Caco-2 cells & $\begin{array}{l}3.37 \mu \mathrm{M} \\
6 \mathrm{~h}\end{array}$ & $\begin{array}{l}\text { Decrease in TEER values } \\
15-A c-D O N>\text { DON }>3 \text {-Ac-DON } \\
\text { Increase in permeability of LY } \\
15-A c-D O N\end{array}$ & Kadota et al. (2013) \\
\hline IPEC -1 cells & $\begin{array}{l}10-30 \mu \mathrm{M} \\
24-48 \mathrm{~h}\end{array}$ & $\begin{array}{l}\text { Decrease in TEER values } \\
\text { Increase in permeability of } 4 \mathrm{kDa} \text { FITC-dextran } \\
15-\text { Ac-DON }>\text { DON }>3 \text {-Ac-DON } \\
\text { Decrease in protein expression of CLDN3 and } \\
\text { CLDN4 } \\
\text { 15-Ac-DON }>\text { DON }=3 \text {-Ac-DON }\end{array}$ & Pinton et al. (2012) \\
\hline
\end{tabular}

DON can cover all age groups, even the developing fetus, since DON crosses the placental barrier (Danicke et al.
2007; Nielsen et al. 2011). Genotoxicity and mutagenicity of DON is widely studied, and IARC has classified DON as 
a group 3 carcinogen (not carcinogenic to humans) (IARC 1993). DON modulates the function of various organ systems. For example, DON is also known as vomitoxin, since it induces a strong emetic effect due to an interaction with the dopaminergic system in the central nervous system (Maresca 2013; Pestka 2010b; Sobrova et al. 2010). Other neurological effects of DON in regulating overall activity and satiety have recently been discussed (Bonnet et al. 2012; Maresca 2013; Yazar and Omurtag 2008). Another important target of DON is the immune system, and DON can induce both immunostimulatory as well as immunosuppressive responses depending on dose, frequency and duration of exposure. As an example, low-dose exposure to DON triggers immune responses, whereas a high dose leads to leukocyte apoptosis and subsequent immunosuppression (Pestka 2007, 2010b). At the cellular level, DON inhibits protein synthesis (at the elongation-termination step of protein translation) through interaction with the peptidyl transferase at the 60S ribosomal subunit (Rocha et al. 2005). The binding of DON to the ribosome rapidly activates MAPK signaling pathways and induces caspasemediated apoptosis in a process known as the "ribotoxic stress response" (Pestka 2010b; Rocha et al. 2005; Wu et al. 2014a).

In addition to DON itself, two acetylated derivatives (3-acetyl DON, 3-Ac-DON and 15-acetyl DON, 15-AcDON) may simultaneously be produced by Fusarium species. Due to similarity in the chemical structure, the mode of action of 3-Ac-DON and 15-Ac-DON is generally considered to be the same as DON (Pestka 2010a, b). Recently, the contribution of plant-derived conjugates, such as glucosides of DON, to overall DON exposure is considered as well (Berthiller et al. 2005).

\section{Effects of DON, 3-Ac-DON and 15-Ac-DON on intestinal barrier function}

The contribution of DON to the loss of intestinal barrier function has been extensively examined in different in vitro, ex vivo and in vivo studies (Table 6). Evidence in different human (Caco-2, T84 and HT-29) as well as porcine (IPEC-1 and IPEC-J2) intestinal epithelial cells has shown that DON induces a concentration- and timedependent drop in TEER values (Akbari et al. 2014; Diesing et al. 2011a; Kasuga et al. 1998; Maresca et al. 2002; Pinton et al. 2012). It could be concluded that IPEC-1 cells are more sensitive to DON compared to Caco- 2 cells as indicated by the DON-induced TEER drop (Pinton et al. 2009). This difference may be associated with different origin and type of these cell lines, as Caco- 2 cells are human colon adenocarcinoma cells, while IPEC-1 cells are non-transformed and non-carcinoma cells obtained from porcine small intestines (Alassane-Kpembi et al. 2015;
Pestka 2007). Recently, we showed that the DON-induced TEER drop considerably depends on the site of application and this response is much more pronounced when DON is applied to the basolateral, rather than the apical surface of Caco- 2 cells (Akbari et al. 2014). The same surfacedependent effect is also observed in IPEC-J2 cells (Diesing et al. 2011a). Using horizontal impedance measurements, we and others could show that DON disintegrates a human Caco-2 cell monolayer within the first few hours of exposure in concentrations as low as $1.5 \mu \mathrm{M}$ (Akbari et al. 2014; Manda et al. 2015). The DON-induced TEER drop in established epithelial cell monolayers is accompanied with a concentration-dependent increase in the flux of paracellular markers such as mannitol, $\mathrm{HRP}, \mathrm{LY}$ and $4 \mathrm{kDa}$ FITC-dextran (Table 6) (Akbari et al. 2014; De Walle et al. 2010; Ling et al. 2016; Maresca et al. 2008). Goossens et al. (2012) observed that the decrease in TEER is accompanied with an increase in passage of smaller molecules such as the antibiotics doxycycline and paromomycin across IPEC-J2 cells. This is in line with the assumption that an increased flux of paracellular markers is size selective, since our study with two molecular sizes of FITC-dextran $(4$ and $40 \mathrm{kDa})$ revealed that DON exposure induces a significant increase in the flux of $4 \mathrm{kDa}$ FITC-dextran in the Caco-2 cells, but not of $40 \mathrm{kDa}$ FITC-dextran (Akbari et al. 2014). A similar concentration-dependent increase in permeability was observed in pig jejunal explants exposed to 20-50 $\mu \mathrm{M}$ DON for up to $2 \mathrm{~h}$ (Pinton et al. 2009). Intestinal barrier breakdown was further confirmed in vivo by our previous study showing that a single oral application of DON $(25 \mathrm{mg} / \mathrm{kg} \mathrm{bw})$ to mice results in significant increase in $4 \mathrm{kDa}$ FITC-dextran permeability (Akbari et al. 2014). Of clinical relevance is the fact that a DON-induced impairment of intestinal integrity may result in the increased transfer of luminal antigens and bacteria. Pinton et al. (2009) described that DON treatment causes a concentration- and time-dependent increase in translocation of pathogenic E. coli across IPEC-1 cell monolayers. Other studies pointed out that DON-induced loss of epithelial barrier function, observed by decrease in TEER and increase in paracellular flux, is correlated with the increase in translocation of commensal E. coli across Caco-2 cells (Ling et al. 2016; Maresca et al. 2008). DON-enhanced translocation of $S$. typhimurium is reported in both undifferentiated and differentiated IPEC-J2 cells, although undifferentiated cells are found to be more sensitive in comparison with differentiated cells (Vandenbroucke et al. 2011). DON-induced permeability in various in vitro and in vivo models is accompanied with specific alterations in the expression (at transcriptional and protein levels) as well as distribution of different TJs. An up-regulation in mRNA levels of CLDN3, CLDN4, OCLN and ZO-1 was observed in DON-exposed Caco-2 cells (Akbari et al. 2014; De Walle et al. 2010; 
Osselaere et al. 2013). CLDNs have been reported to be the most susceptible TJs regarding DON exposure to human intestinal epithelial cells (Akbari et al. 2014; Maresca and Fantini 2010; Pinton et al. 2009, 2012). However, in addition to CLDNs, OCLN and ZO-1 have also been shown to be influenced by DON in porcine intestinal epithelial cells (Diesing et al. 2011a, b; Gu et al. 2014; Ling et al. 2016).

Up-regulation of TJ mRNA is often reported as an effect of DON, whereas at the same time, a significant reduction in the protein level of different TJs is observed (Akbari et al. 2014; Bol-Schoenmakers et al. 2016; De Walle et al. 2010; Ling et al. 2016). Therefore, it is assumed that DON primarily targets the TJ proteins and that the RNA up-regulation needs to be considered as a compensatory mechanism (Akbari et al. 2014; Alizadeh et al. 2015; BolSchoenmakers et al. 2016; De Walle et al. 2010; Ling et al. 2016; Osselaere et al. 2013). Another explanation could be that in addition to protein synthesis inhibition (which could explain the decrease in protein level of TJs), DON augments and prolongs the usually transient expression of genes either by transcriptional enhancement or transcript stabilization (leading to increased transcriptional rates of TJs), a mechanism described as superinduction (AzconaOlivera et al. 1995a, b).

In vivo exposure to DON-contaminated diet also significantly affects different TJs, and segment-specific effects of DON are reported to occur throughout the intestine. Our previous study, as an example, indicated that up-regulation of the different CLDNs caused by a gavage with DON is most pronounced in the mouse distal small intestine compared to other segments of the intestine (Akbari et al. 2014). Surprisingly, our group found that even after low-level exposure to DON, which has been generally considered as acceptable in animal feeds, substantial changes occur in markers of intestinal integrity. For example, upregulation of different $\mathrm{TJ}$ proteins were observed alongside the intestine, whereas in the jejunum, the mRNA expression of certain TJs (CLDN4, OCLN, ZO-1 and ZO-2) was down-regulated (Alizadeh et al. 2015). Furthermore, Lessard et al. (2015) also observed the down-regulation of CLDN3, CLDN4 and OCLN mRNA levels in the ileum of pigs consuming a DON-contaminated diet, whereas no effect was observed in the jejunum. A study conducted in broiler chickens showed an up-regulation of CLDN1, CLDN5, ZO-1 and ZO-2 mRNA levels in the ileum after dietary DON exposure, while only CLDN5 was affected in the jejunum (Osselaere et al. 2013).

Bol-Schoenmakers et al. (2016) described that single oral exposure of mice to DON (25 $\mathrm{mg} / \mathrm{kg} \mathrm{bw})$ results in a time-dependent decrease in the CLDN3 protein expression observed in the duodenum. In addition, several studies demonstrated a decrease in protein expression of CLDN4 and OCLN in pig jejunum and ileum after a DON diet
(Bracarense et al. 2012; Pinton et al. 2009). In contrast to other studies, Alizadeh et al. (2015) showed that the protein expression of OCLN is significantly increased in duodenum, jejunum and colon of DON-treated pigs compared to control animals, which is probably related to the low-dose exposure to DON in this study. In addition, DON is able to interrupt the distribution pattern of TJs (including CLDNs, OCLN and ZO-1) as demonstrated within different in vitro as well as in vivo models (Akbari et al. 2014; Diesing et al. 2011a, b). Our recent murine study showed that already $6 \mathrm{~h}$ after an oral DON gavage $(25 \mathrm{mg} / \mathrm{kg} \mathrm{bw})$, an irregular distribution of CLDN1, CLDN2 and CLDN3 has been observed in the distal small intestine, whereas in the colon no differences in the TJ distribution pattern were detected (Akbari et al. 2014).

Unlike well-documented effects of DON on gut barrier, knowledge about toxicity of its acetylated derivatives is still limited and only a few studies have addressed intestinal barrier impairment induced by 3-Ac-DON and 15-Ac-DON (Table 6). Kadota et al. (2013) showed that 15-Ac-DON has a higher potency to affect the permeability of Caco-2 cells compared to DON and 3-Ac-DON. The potency of DON and its acetylated derivatives on the barrier function of IPEC-1 cells are ranked as 15-Ac-DON > DON > 3-AcDON based on the decrease in TEER values and the increase in the permeability of $4 \mathrm{kDa}$ FITC-dextran. Measuring the protein expression of CLDNs clearly showed that 15 -Ac-DON has a more pronounced effect on the expression of CLDN3 and CLDN4 in IPEC-1 cells compared to DON and 3-Ac-DON (Pinton et al. 2012).

As mentioned above, interaction of DON with the peptidyl transferase at the 60S ribosomal subunit has been associated not only with translational arrest and protein synthesis inhibition, but also with an activation of the intracellular protein kinases (particularly MAPKs) and their downstream signaling partners in a process known as the ribotoxic stress response (Pestka 2010a; Pinton et al. 2012; Plotnikov et al. 2011; Wang et al. 2014). MAPKs play a crucial role in many physiological processes including cell growth, differentiation, apoptosis and immune responses (Plotnikov et al. 2011). Further studies have shown that TJ structure and function can also be regulated by signaling molecules involved in MAPK pathways (Matter and Balda 2003; McLaughlin et al. 2009). At the molecular level, MAPK extracellular signal-regulated kinase 1 and 2 (ERK1/2), c-Jun N-terminal kinase (JNK) and p38 are described to get rapidly activated by DON in human as well as porcine intestinal cell lines (Pinton et al. 2012; Sergent et al. 2006), and this activation leads to a decrease in the expression of CLDNs (Pinton et al. 2010, 2012).

Different observations of DON-induced activation of MAPKs have been reported in ex vivo as well as in vivo models. Using IPEC-1 cells, Pinton et al. (2010) showed 
Table 7 Aspect of TJ-related barrier dysfunction in chronic intestinal inflammatory diseases

\begin{tabular}{|c|c|c|}
\hline Inflammatory disease & TJ proteins & References \\
\hline Crohn's disease & $\begin{array}{l}\downarrow \text { OCLN }, \downarrow \text { CLDN3, } \downarrow \text { CLDN5, } \downarrow \text { CLDN8, } \downarrow \text { JAM } \\
\uparrow \text { CLDN2 } \\
\text { Redistribution of OCLN, CLDN3, CLDN5, CLDN8 }\end{array}$ & Prasad et al. (2005), Vetrano et al. (2008), Zeissig et al. (2007) \\
\hline Ulcerative colitis & $\begin{array}{l}\downarrow \text { OCLN }, \downarrow \text { CLDN1, } \downarrow \text { CLDN4 }, \downarrow J A M, \downarrow \text { Tricellulin } \\
\uparrow C L D N 2 \\
\text { Redistribution of OCLN, CLDN1, CLDN4 }\end{array}$ & $\begin{array}{l}\text { Heller et al. (2005), Hering et al. (2012), Prasad et al. (2005), } \\
\text { Vetrano et al. (2008) }\end{array}$ \\
\hline Celiac disease & $\begin{array}{l}\downarrow \text { OCLN }, \downarrow Z \mathrm{ZO}-1 \\
\uparrow \mathrm{CLDN} 2, \uparrow \mathrm{CLDN} 3 \\
\text { Redistribution of OCLN }\end{array}$ & Drago et al. (2006), Szakal et al. (2010) \\
\hline Irritable bowel syndrome & $\begin{array}{l}\downarrow \text { OCLN }, \downarrow \text { CLDN1, } \downarrow \text { ZO-1 } \\
\text { Redistribution of OCLN, CLDN1, ZO-1 }\end{array}$ & Bertiaux-Vandaele et al. (2011) \\
\hline
\end{tabular}

Expression: $\downarrow$ decrease, $\uparrow$ increase

that the DON-activated MAPK ERK1/2 correlates with a reduction in barrier function observed by decrease in TEER, increase in paracellular permeability and decrease in the expression of CLDN4. Interestingly, inhibition of ERK1/2 phosphorylation restored the barrier function of differentiated IPEC-1 cells (Pinton et al. 2010). In addition, a study conducted by the same author showed that none of the MAPKs, such as ERK1/2, JNK and p38, are significantly activated neither in ex vivo (pig jejunal explants exposed to DON) nor in in vivo (jejunum of DON-fed pigs) models (Pinton et al. 2012). However, another study using the same ex vivo and in vivo approaches reported that DON significantly enhances the phosphorylation of ERK1/2 and p38, whereas the phosphorylation of JNK remains unaffected (Lucioli et al. 2013).

Only a few studies displayed differences between DON and its acetylated derivatives regarding their potency to activate MAPKs. 15-Ac-DON, as an example, has a greater capacity to activate MAPK ERK1/2, p38 and JNK, in the porcine intestinal epithelial cells and in pig jejunal explants compared to DON and 3-Ac-DON (Pinton et al. 2012).

\section{Clinical relevance and conclusions}

A dynamic and well-regulated intestinal barrier is essential to protect the body against dietary antigens and residential intestinal microbiota. This barrier is created by an impermeable layer of epithelial cells, sealed by specific TJ proteins preventing the paracellular diffusion of luminal antigens and microorganisms (Fig. 1). An impaired intestinal barrier leads to mucosal inflammation and has been linked to the pathogenesis of various chronic intestinal inflammatory diseases, such as Crohn's disease, ulcerative colitis, celiac disease and irritable bowel syndrome (Bertiaux-Vandaele et al. 2011; Drago et al. 2006; Gibson 2004; Hering et al. 2012; Suzuki 2013; Vetrano et al. 2008). TJ proteins, which seal the epithelial monolayer, are one of the most important functional elements of the intestinal barrier, and a decrease in the abundance and a the re-distribution of different TJ proteins are observed in all major chronic intestinal inflammatory diseases as summarized in Table 7.

Dietary exposure of humans and animals to mycotoxins is of growing concern due to the apparently still increasing prevalence of these fungal toxins in food and feed commodities (Bhat et al. 2010; Marin et al. 2013; Rodrigues and Naehrer 2012; Wu et al. 2014a). Due to this increasing prevalence in food commodities, mycotoxins appear to be important, but often neglected substances that are able to affect TJ proteins and impair the integrity of the intestinal barrier. Even though mycotoxins have not been associated with a specific intestinal disease, the investigations summarized above demonstrate that mycotoxins impair the expression and function of TJ proteins in different ways. Among the various mycotoxins, particularly DON has been identified to modulate the expression, intracellular localization and function of TJ proteins (Fig. 1), while PAT seems to directly affect the epithelial cell monolayer. PAT is only found incidentally as a contaminant of fruit juices and other fruit products, whereas DON is found in major food supplies, such as wheat and other cereal products, which are consumed daily. This continuing exposure suggests a role of this mycotoxin in the etiology of chronic intestinal inflammatory diseases. The observation that even pathogenic bacteria are translocated from the intestinal lumen to the internal environment, when animals are challenged with mycotoxins confirms their significance in inflammatory reactions. Moreover, considering the apparent lactational transfer of various mycotoxins (transfer from maternal plasma into milk), exposure of infants deserves special attention. Even minor changes in the (developing) barrier function can lead to exposure to luminal antigens in early phases of life and may result in accelerated immunological responses and clinical manifestations, such as allergies 
in later stages of life. The prevalence of wheat allergy in children is increasing (Cianferoni et al. 2013; Makela et al. 2014; Sievers et al. 2015), and as DON is mainly found in wheat and wheat-derived products, it cannot be excluded that DON plays also a role in the onset of allergic reactions in children. Further studies should be devoted to the effects of frequently occurring mycotoxins in human food supplies on TJ proteins, and their effect on the intestinal barrier should be included in the overall risk assessment of mycotoxins in foods.

\section{Compliance with ethical standards}

Conflict of interest The authors declare that they have no conflict of interest.

Open Access This article is distributed under the terms of the Creative Commons Attribution 4.0 International License (http://creativecommons.org/licenses/by/4.0/), which permits unrestricted use, distribution, and reproduction in any medium, provided you give appropriate credit to the original author(s) and the source, provide a link to the Creative Commons license, and indicate if changes were made.

\section{References}

Abassi YA, Xi B, Zhang W, Ye P, Kirstein SL, Gaylord MR, Feinstein SC, Wang X, Xu X (2009) Kinetic cell-based morphological screening: prediction of mechanism of compound action and off-target effects. Chem Biol 16:712-723. doi:10.1016/j. chembiol.2009.05.011

Abid-Essefi S, Baudrimont I, Hassen W, Ouanes Z, Mobio TA, Anane R, Creppy EE, Bacha H (2003) DNA fragmentation, apoptosis and cell cycle arrest induced by zearalenone in cultured DOK, Vero and Caco-2 cells: prevention by Vitamin E. Toxicology 192:237-248. doi:10.1016/S0300-483X(03)00329-9

Abid-Essefi S, Ouanes Z, Hassen W, Baudrimont I, Creppy E, Bacha $\mathrm{H}$ (2004) Cytotoxicity, inhibition of DNA and protein syntheses and oxidative damage in cultured cells exposed to zearalenone. Toxicol In Vitro 18:467-474. doi:10.1016/j.tiv.2003.12.011

Akbari P, Braber S, Gremmels H, Koelink PJ, Verheijden KA, Garssen J, Fink-Gremmels J (2014) Deoxynivalenol: a trigger for intestinal integrity breakdown. FASEB J 28:2414-2429. doi:10.1096/fj.13-238717

Alassane-Kpembi I, Kolf-Clauw M, Gauthier T, Abrami R, Abiola FA, Oswald IP, Puel O (2013) New insights into mycotoxin mixtures: the toxicity of low doses of Type B trichothecenes on intestinal epithelial cells is synergistic. Toxicol Appl Pharmacol 272:191-198. doi:10.1016/j.taap.2013.05.023

Alassane-Kpembi I, Puel O, Oswald IP (2015) Toxicological interactions between the mycotoxins deoxynivalenol, nivalenol and their acetylated derivatives in intestinal epithelial cells. Arch Toxicol 89:1337-1346. doi:10.1007/s00204-014-1309-4

Alizadeh A, Braber S, Akbari P, Garssen J, Fink-Gremmels J (2015) Deoxynivalenol impairs weight gain and affects markers of gut health after low-dose, short-term exposure of growing pigs. Toxins (Basel) 7:2071-2095. doi:10.3390/toxins7062071

Arrieta MC, Bistritz L, Meddings JB (2006) Alterations in intestinal permeability. Gut 55:1512-1520. doi:10.1136/gut.2005.085373
Artursson P, Palm K, Luthman K (2012) Caco-2 monolayers in experimental and theoretical predictions of drug transport. Adv Drug Deliv Rev 64:280-289. doi:10.1016/S0169-409X(00)00128-9

Assuncao R, Ferreira M, Martins C, Diaz I, Padilla B, Dupont D, Braganca M, Alvito P (2014) Applicability of in vitro methods to study patulin bioaccessibility and its effects on intestinal membrane integrity. J Toxicol Environ Health A 77:983-992. doi:10. 1080/15287394.2014.911138

Assuncao R, Alvito P, Kleiveland CR, Lea TE (2016) Characterization of in vitro effects of patulin on intestinal epithelial and immune cells. Toxicol Lett 250-251:47-56. doi:10.1016/j. toxlet.2016.04.007

Azcona-Olivera JI, Ouyang Y, Murtha J, Chu FS, Pestka JJ (1995a) Induction of cytokine mRNAs in mice after oral exposure to the trichothecene vomitoxin (deoxynivalenol): relationship to toxin distribution and protein synthesis inhibition. Toxicol Appl Pharmacol 133:109-120. doi:10.1006/taap.1995.1132

Azcona-Olivera JI, Ouyang YL, Warner RL, Linz JE, Pestka JJ (1995b) Effects of vomitoxin (deoxynivalenol) and cycloheximide on IL-2, 4, 5 and 6 secretion and mRNA levels in murine CD4 + cells. Food Chem Toxicol 33:433-441. doi:10.1016/0278-6915(95)00012-Q

Balavenkatraman KK, Jandt E, Friedrich K, Kautenburger T, PoolZobel BL, Ostman A, Bohmer FD (2006) DEP-1 protein tyrosine phosphatase inhibits proliferation and migration of colon carcinoma cells and is upregulated by protective nutrients. Oncogene 25:6319-6324. doi:10.1038/sj.onc.1209647

Bedard LL, Massey TE (2006) Aflatoxin B1-induced DNA damage and its repair. Cancer Lett 241:174-183. doi:10.1016/j. canlet.2005.11.018

Bennett JW, Klich M (2003) Mycotoxins. Clin Microbiol Rev 16:497-516. doi:10.1128/CMR.16.3.497-516.2003

Benson K, Cramer S, Galla HJ (2013) Impedance-based cell monitoring: barrier properties and beyond. Fluids Barriers CNS 10:5. doi:10.1186/2045-8118-10-5

Berger V, Gabriel AF, Sergent T, Trouet A, Larondelle Y, Schneider YJ (2003) Interaction of ochratoxin A with human intestinal Caco-2 cells: possible implication of a multidrug resistanceassociated protein (MRP2). Toxicol Lett 140-141:465-476. doi:10.1016/S0378-4274(03)00043-2

Berthiller F, Dall'Asta C, Schuhmacher R, Lemmens M, Adam G, Krska R (2005) Masked mycotoxins: determination of a deoxynivalenol glucoside in artificially and naturally contaminated wheat by liquid chromatography-tandem mass spectrometry. J Agric Food Chem 53:3421-3425. doi:10.1021/jf047798g

Bertiaux-Vandaele N, Youmba SB, Belmonte L, Lecleire S, Antonietti M, Gourcerol G, Leroi AM, Dechelotte P, Menard JF, Ducrotte P, Coeffier M (2011) The expression and the cellular distribution of the tight junction proteins are altered in irritable bowel syndrome patients with differences according to the disease subtype. Am J Gastroenterol 106:2165-2173. doi:10.1038/ ajg.2011.257

Bhat R, Rai RV, Karim AA (2010) Mycotoxins in food and feed: present status and future concerns. Compr Rev Food Sci Food Saf 9:57-81. doi:10.1111/j.1541-4337.2009.00094.x

Bianco G, Fontanella B, Severino L, Quaroni A, Autore G, Marzocco S (2012) Nivalenol and deoxynivalenol affect rat intestinal epithelial cells: a concentration related study. PLoS ONE 7:e52051. doi:10.1371/journal.pone.0052051

Bischoff SC, Barbara G, Buurman W, Ockhuizen T, Schulzke JD, Serino M, Tilg H, Watson A, Wells JM (2014) Intestinal permeability: a new target for disease prevention and therapy. BMC Gastroenterol 14:189. doi:10.1186/s12876-014-0189-7

Bjarnason I, MacPherson A, Hollander D (1995) Intestinal permeability: an overview. Gastroenterology 108:1566-1581. doi:10.1016/0016-5085(95)90708-4 
Blikslager AT, Moeser AJ, Gookin JL, Jones SL, Odle J (2007) Restoration of barrier function in injured intestinal mucosa. Physiol Rev 87:545-564. doi:10.1152/physrev.00012.2006

Bol-Schoenmakers M, Braber S, Akbari P, de Graaff P, van Roest M, Kruijssen L, Smit JJ, van Esch BC, Jeurink PV, Garssen J, FinkGremmels J, Pieters RH (2016) The mycotoxin deoxynivalenol facilitates allergic sensitization to whey in mice. Mucosal Immunol. doi: 10.1038/mi.2016.13

Bonnet MS, Roux J, Mounien L, Dallaporta M, Troadec JD (2012) Advances in deoxynivalenol toxicity mechanisms: the brain as a target. Toxins (Basel) 4:1120-1138. doi:10.3390/toxins4111120

Bouhet S, Oswald IP (2005) The effects of mycotoxins, fungal food contaminants, on the intestinal epithelial cell-derived innate immune response. Vet Immunol Immunopathol 108:199-209. doi:10.1016/j.vetimm.2005.08.010

Bouhet S, Oswald IP (2007) The intestine as a possible target for fumonisin toxicity. Mol Nutr Food Res 51:925-931. doi:10.1002/mnfr.200600266

Bouhet S, Hourcade E, Loiseau N, Fikry A, Martinez S, Roselli M, Galtier P, Mengheri E, Oswald IP (2004) The mycotoxin fumonisin $\mathrm{B} 1$ alters the proliferation and the barrier function of porcine intestinal epithelial cells. Toxicol Sci 77:165-171. doi:10.1093/toxsci/kfh006

Boussabbeh M, Ben Salem I, Prola A, Guilbert A, Bacha H, AbidEssefi S, Lemaire C (2015) Patulin induces apoptosis through ROS-mediated endoplasmic reticulum stress pathway. Toxicol Sci 144:328-337. doi:10.1093/toxsci/kfu319

Bracarense AP, Lucioli J, Grenier B, Drociunas Pacheco G, Moll WD, Schatzmayr G, Oswald IP (2012) Chronic ingestion of deoxynivalenol and fumonisin, alone or in interaction, induces morphological and immunological changes in the intestine of piglets. Br J Nutr 107:1776-1786. doi:10.1017/S0007114511004946

Caloni F, Stammati AL, Raimondi F, De Angelis I (2005) In vitro study with Caco-2 cells on fumonisin B1: aminopentol intestinal passage and role of P-glycoprotein. Vet Res Commun 29(Suppl 2):285-287. doi:10.1007/s11259-005-0063-8

Caloni F, Stammati A, Frigge G, De Angelis I (2006) Aflatoxin M1 absorption and cytotoxicity on human intestinal in vitro model. Toxicon 47:409-415. doi:10.1016/j.toxicon.2005.12.003

Caloni F, Cortinovis C, Pizzo F, De Angelis I (2012) Transport of Aflatoxin M(1) in Human Intestinal Caco-2/TC7 Cells. Front Pharmacol 3:111. doi:10.3389/fphar.2012.00111

Calvert TW, Aidoo KE, Candlish AG, Fuat AR (2005) Comparison of in vitro cytotoxicity of Fusarium mycotoxins, deoxynivalenol, T-2 toxin and zearalenone on selected human epithelial cell lines. Mycopathologia 159:413-419. doi:10.1007/ s11046-005-0254-4

Chaudhari M, Jayaraj R, Bhaskar AS, Lakshmana Rao PV (2009) Oxidative stress induction by $\mathrm{T}-2$ toxin causes DNA damage and triggers apoptosis via caspase pathway in human cervical cancer cells. Toxicology 262:153-161. doi:10.1016/j. tox.2009.06.002

Cheat S, Gerez JR, Cognie J, Alassane-Kpembi I, Bracarense AP, Raymond-Letron I, Oswald IP, Kolf-Clauw M (2015) Nivalenol has a greater impact than deoxynivalenol on pig jejunum mucosa in vitro on explants and in vivo on intestinal loops. Toxins (Basel) 7:1945-1961. doi:10.3390/toxins7061945

Chen X, Naehrer K, Applegate TJ (2016) Interactive effects of dietary protein concentration and aflatoxin B1 on performance, nutrient digestibility, and gut health in broiler chicks. Poult Sci. doi: $10.3382 / \mathrm{ps} /$ pew022

Chiba H, Osanai M, Murata M, Kojima T, Sawada N (2008) Transmembrane proteins of tight junctions. Biochim Biophys Acta 1778:588-600. doi:10.1016/j.bbamem.2007.08.017

Chu FS, Li GY (1994) Simultaneous occurrence of fumonisin B1 and other mycotoxins in moldy corn collected from the People's
Republic of China in regions with high incidences of esophageal cancer. Appl Environ Microbiol 60:847-852

Cianferoni A, Khullar K, Saltzman R, Fiedler J, Garrett JP, Naimi DR, Spergel JM (2013) Oral food challenge to wheat: a nearfatal anaphylaxis and review of 93 food challenges in children. World Allergy Organ J 6:14. doi:10.1186/1939-4551-6-14

Danicke S, Brussow KP, Goyarts T, Valenta H, Ueberschar KH, Tiemann U (2007) On the transfer of the Fusarium toxins deoxynivalenol (DON) and zearalenone ( $\mathrm{ZON})$ from the sow to the full-term piglet during the last third of gestation. Food Chem Toxicol 45:1565-1574. doi:10.1016/j.fct.2007.02.016

De Walle JV, Sergent T, Piront N, Toussaint O, Schneider YJ, Larondelle Y (2010) Deoxynivalenol affects in vitro intestinal epithelial cell barrier integrity through inhibition of protein synthesis. Toxicol Appl Pharmacol 245:291-298. doi:10.1016/j. taap.2010.03.012

Del Regno M, Adesso S, Popolo A, Quaroni A, Autore G, Severino L, Marzocco S (2015) Nivalenol induces oxidative stress and increases deoxynivalenol pro-oxidant effect in intestinal epithelial cells. Toxicol Appl Pharmacol 285:118-127. doi:10.1016/j. taap.2015.04.002

DeMeo MT, Mutlu EA, Keshavarzian A, Tobin MC (2002) Intestinal permeation and gastrointestinal disease. J Clin Gastroenterol 34:385-396

Diesing AK, Nossol C, Danicke S, Walk N, Post A, Kahlert S, Rothkotter HJ, Kluess J (2011a) Vulnerability of polarised intestinal porcine epithelial cells to mycotoxin deoxynivalenol depends on the route of application. PLoS ONE 6:e17472. doi:10.1371/journal.pone.0017472

Diesing AK, Nossol C, Panther P, Walk N, Post A, Kluess J, Kreutzmann P, Danicke S, Rothkotter HJ, Kahlert S (2011b) Mycotoxin deoxynivalenol (DON) mediates biphasic cellular response in intestinal porcine epithelial cell lines IPEC-1 and IPEC-J2. Toxicol Lett 200:8-18. doi:10.1016/j. toxlet.2010.10.006

Drago S, El Asmar R, Di Pierro M, Grazia Clemente M, Tripathi A, Sapone A, Thakar M, Iacono G, Carroccio A, D'Agate C, Not T, Zampini L, Catassi C, Fasano A (2006) Gliadin, zonulin and gut permeability: effects on celiac and non-celiac intestinal mucosa and intestinal cell lines. Scand J Gastroenterol 41:408419. doi:10.1080/00365520500235334

EFSA (2013) Scientific Opinion on risks for animal and public health related to the presence of nivalenol in food and feed. EFSA J 11:3262

Egner PA, Yu X, Johnson JK, Nathasingh CK, Groopman JD, Kensler TW, Roebuck BD (2003) Identification of aflatoxin M1-N7-guanine in liver and urine of tree shrews and rats following administration of aflatoxin B1. Chem Res Toxicol 16:1174-1180. doi:10.1021/tx034106u

Enongene EN, Sharma RP, Bhandari N, Voss KA, Riley RT (2000) Disruption of sphingolipid metabolism in small intestines, liver and kidney of mice dosed subcutaneously with fumonisin B1. Food Chem Toxicol 38:793-799

Escriva L, Font G, Manyes L (2015) In vivo toxicity studies of fusarium mycotoxins in the last decade: a review. Food Chem Toxicol 78:185-206. doi:10.1016/j.fct.2015.02.005

Fasano A (2011) Zonulin and its regulation of intestinal barrier function: the biological door to inflammation, autoimmunity, and cancer. Physiol Rev 91:151-175. doi:10.1152/ physrev.00003.2008

Fasano A (2012) Zonulin, regulation of tight junctions, and autoimmune diseases. Ann N Y Acad Sci 1258:25-33. doi:10.1111/j.1749-6632.2012.06538.x

Fink-Gremmels J (2005) Ochratoxin A in food: recent developments and significance. Food Addit Contam 22(Suppl 1):1-5. doi:10.1080/02652030500358415 
Fink-Gremmels J, Jahn A, Blom MJ (1995) Toxicity and metabolism of ochratoxin A. Nat Toxins 3:214-220. doi:10.1002/ nt.2620030408 (discussion 221)

Fliege R, Metzler M (2000) Electrophilic properties of patulin. N-acetylcysteine and glutathione adducts. Chem Res Toxicol 13:373381. doi:10.1021/tx9901480

Furuhashi M, Hotamisligil GS (2008) Fatty acid-binding proteins: role in metabolic diseases and potential as drug targets. Nat Rev Drug Discov 7:489-503. doi:10.1038/nrd2589

Galarza-Seeber R, Latorre JD, Bielke LR, Kuttappan VA, Wolfenden AD, Hernandez-Velasco X, Merino-Guzman R, Vicente JL, Donoghue A, Cross D, Hargis BM, Tellez G (2016) Leaky gut and mycotoxins: aflatoxin B1 does not increase gut permeability in broiler chickens. Front Vet Sci 3:10. doi:10.3389/ fvets.2016.00010

Gelineau-van Waes J, Starr L, Maddox J, Aleman F, Voss KA, Wilberding J, Riley RT (2005) Maternal fumonisin exposure and risk for neural tube defects: mechanisms in an in vivo mouse model. Birth Defects Res A Clin Mol Teratol 73:487497. doi:10.1002/bdra.20148

Gibson PR (2004) Increased gut permeability in Crohn's disease: is TNF the link? Gut 53:1724-1725. doi:10.1136/gut.2004.047092

Goossens J, Pasmans F, Verbrugghe E, Vandenbroucke V, De Baere S, Meyer E, Haesebrouck F, De Backer P, Croubels S (2012) Porcine intestinal epithelial barrier disruption by the Fusarium mycotoxins deoxynivalenol and T-2 toxin promotes transepithelial passage of doxycycline and paromomycin. BMC Vet Res 8:245. doi:10.1186/1746-6148-8-245

Gratz S, Wu QK, El-Nezami H, Juvonen RO, Mykkanen H, Turner PC (2007) Lactobacillus rhamnosus strain GG reduces aflatoxin B1 transport, metabolism, and toxicity in Caco-2 Cells. Appl Environ Microbiol 73:3958-3964. doi:10.1128/AEM.02944-06

Grenier B, Applegate TJ (2013) Modulation of intestinal functions following mycotoxin ingestion: meta-analysis of published experiments in animals. Toxins (Basel) 5:396-430. doi:10.3390/ toxins5020396

Grollman AP, Jelakovic B (2007) Role of environmental toxins in endemic (Balkan) nephropathy. October 2006, Zagreb. Croatia. J Am Soc Nephrol 18:2817-2823. doi:10.1681/ ASN.2007050537

Groschwitz KR, Hogan SP (2009) Intestinal barrier function: molecular regulation and disease pathogenesis. J Allergy Clin Immunol 124:3-20. doi:10.1016/j.jaci.2009.05.038 (quiz 21-22)

Gu MJ, Song SK, Park SM, Lee IK, Yun CH (2014) Bacillus subtilis protects porcine intestinal barrier from deoxynivalenol via improved zonula occludens-1 expression. Asian-Australas J Anim Sci 27:580-586. doi:10.5713/ajas.2013.13744

Hamid AS, Tesfamariam IG, Zhang Y, Zhang ZG (2013) Aflatoxin B1-induced hepatocellular carcinoma in developing countries: geographical distribution, mechanism of action and prevention. Oncol Lett 5:1087-1092. doi:10.3892/ol.2013.1169

Hassen W, Ayed-Boussema I, Oscoz AA, Lopez Ade C, Bacha H (2007) The role of oxidative stress in zearalenone-mediated toxicity in Hep G2 cells: oxidative DNA damage, gluthatione depletion and stress proteins induction. Toxicology 232:294302. doi:10.1016/j.tox.2007.01.015

Heller F, Florian P, Bojarski C, Richter J, Christ M, Hillenbrand B, Mankertz J, Gitter AH, Burgel N, Fromm M, Zeitz M, Fuss I, Strober W, Schulzke JD (2005) Interleukin-13 is the key effector Th2 cytokine in ulcerative colitis that affects epithelial tight junctions, apoptosis, and cell restitution. Gastroenterology 129:550-564. doi:10.1016/j.gastro.2005.05.002

Hepworth SJ, Hardie LJ, Fraser LK, Burley VJ, Mijal RS, Wild CP, Azad R, McKinney PA, Turner PC (2012) Deoxynivalenol exposure assessment in a cohort of pregnant women from
Bradford, UK. Food Addit Contam Part A 29:269-276. doi:10.1 080/19440049.2010.551301

Hering NA, Fromm M, Schulzke JD (2012) Determinants of colonic barrier function in inflammatory bowel disease and potential therapeutics. J Physiol 590:1035-1044. doi:10.1113/ jphysiol.2011.224568

Hidalgo IJ, Raub TJ, Borchardt RT (1989) Characterization of the human colon carcinoma cell line (Caco-2) as a model system for intestinal epithelial permeability. Gastroenterology 96:736-749

Hsia CC, Wu ZY, Li YS, Zhang F, Sun ZT (2004) Nivalenol, a main Fusarium toxin in dietary foods from high-risk areas of cancer of esophagus and gastric cardia in China, induced benign and malignant tumors in mice. Oncol Rep 12:449-456. doi:10.3892/ or.12.2.449

IARC (1987) IARC monographs on the evaluation of carcinogenic risks to humans. International Agency for Research on Cancer Press, Lyon, France 1-42

IARC (1993) IARC monographs on the evaluation of carcinogenic risks to humans: some naturally occuring substances: food items and constitutions, heterocyclic aromatic amines and mycotoxins. International Agency for Research on Cancer Press, Lyon, p 56

IARC (2002) IARC monographs on the evaluation of carcinogenic risks to humans: some traditional herbal medicines, some mycotoxins, napthalene and styrene. International Agency for Research on Cancer Press, Lyon, p 82

Jimison LH, Tria SA, Khodagholy D, Gurfinkel M, Lanzarini E, Hama A, Malliaras GG, Owens RM (2012) Measurement of barrier tissue integrity with an organic electrochemical transistor. Adv Mater 24:5919-5923. doi:10.1002/adma.201202612

Joffe AZ (1971) Alimentary toxic aleukia. Alimentary toxic aleukia. In: Kadis S, Ciegler A, Ajl SJ (eds) Microbiol toxins, vol 7. Academic Press, New York, pp 139-189

Kadota T, Furusawa H, Hirano S, Tajima O, Kamata Y, Sugita-Konishi Y (2013) Comparative study of deoxynivalenol, 3-acetyldeoxynivalenol, and 15-acetyldeoxynivalenol on intestinal transport and IL-8 secretion in the human cell line Caco-2. Toxicol In Vitro 27:1888-1895. doi:10.1016/j.tiv.2013.06.003

Kanai K, Kondo E (1984) Decreased resistance to mycobacterial infection in mice fed a trichothecene compound (T-2 toxin). Jpn J Med Sci Biol 37:97-104

Kasuga F, Hara-Kudo Y, Saito N, Kumagai S, Sugita-Konishi Y (1998) In vitro effect of deoxynivalenol on the differentiation of human colonic cell lines Caco-2 and T84. Mycopathologia 142:161-167. doi:10.1023/A:923808748

Katsuyama A, Konno T, Shimoyama S, Kikuchi H (2014) The mycotoxin patulin decreases expression of density-enhanced phosphatase- 1 by down-regulating PPARgamma in human colon cancer cells. Tohoku J Exp Med 233:265-274. doi:10.1620/ tjem.233.265

Kawauchiya T, Takumi R, Kudo Y, Takamori A, Sasagawa T, Takahashi K, Kikuchi H (2011) Correlation between the destruction of tight junction by patulin treatment and increase of phosphorylation of ZO-1 in Caco-2 human colon cancer cells. Toxicol Lett 205:196-202. doi:10.1016/j.toxlet.2011.06.006

Kleinova M, Zollner P, Kahlbacher H, Hochsteiner W, Lindner W (2002) Metabolic profiles of the mycotoxin zearalenone and of the growth promoter zeranol in urine, liver, and muscle of heifers. J Agric Food Chem 50:4769-4776. doi:10.1021/jf020160p

Kolf-Clauw M, Castellote J, Joly B, Bourges-Abella N, RaymondLetron I, Pinton P, Oswald IP (2009) Development of a pig jejunal explant culture for studying the gastrointestinal toxicity of the mycotoxin deoxynivalenol: histopathological analysis. Toxicol In Vitro 23:1580-1584. doi:10.1016/j.tiv.2009.07.015 
Kolf-Clauw M, Sassahara M, Lucioli J, Rubira-Gerez J, AlassaneKpembi I, Lyazhri F, Borin C, Oswald IP (2013) The emerging mycotoxin, enniatin B1, down-modulates the gastrointestinal toxicity of T-2 toxin in vitro on intestinal epithelial cells and ex vivo on intestinal explants. Arch Toxicol 87:2233-2241. doi:10.1007/s00204-013-1067-8

Kouadio JH, Mobio TA, Baudrimont I, Moukha S, Dano SD, Creppy EE (2005) Comparative study of cytotoxicity and oxidative stress induced by deoxynivalenol, zearalenone or fumonisin B1 in human intestinal cell line Caco-2. Toxicology 213:56-65. doi:10.1016/j.tox.2005.05.010

Lalles JP, Lessard M, Boudry G (2009) Intestinal barrier function is modulated by short-term exposure to fumonisin B1 in Ussing chambers. Vet Res Commun 33:1039-1043. doi:10.1007/ s11259-009-9310-8

Lambert D, Padfield PJ, McLaughlin J, Cannell S, O’Neill CA (2007) Ochratoxin A displaces claudins from detergent resistant membrane microdomains. Biochem Biophys Res Commun 358:632636. doi:10.1016/j.bbrc.2007.04.180

Leong YH, Latiff AA, Ahmad NI, Rosma A (2012) Exposure measurement of aflatoxins and aflatoxin metabolites in human body fluids. A short review. Mycotoxin Res 28:79-87. doi:10.1007/ s12550-012-0129-8

Lessard M, Savard C, Deschene K, Lauzon K, Pinilla VA, Gagnon CA, Lapointe J, Guay F, Chorfi Y (2015) Impact of deoxynivalenol (DON) contaminated feed on intestinal integrity and immune response in swine. Food Chem Toxicol 80:7-16. doi:10.1016/j.fct.2015.02.013

Li Y, Wang Z, Beier RC, Shen J, De Smet D, De Saeger S, Zhang S (2011) T-2 toxin, a trichothecene mycotoxin: review of toxicity, metabolism, and analytical methods. J Agric Food Chem 59:3441-3453. doi:10.1021/jf200767q

Ling KH, Wan ML, El-Nezami H, Wang M (2016) Protective capacity of resveratrol, a natural polyphenolic compound, against deoxynivalenol-induced intestinal barrier dysfunction and bacterial translocation. Chem Res Toxicol 29:823-833. doi:10.1021/acs. chemrestox.6b00001

Liu Y, Wu F (2010) Global burden of aflatoxin-induced hepatocellular carcinoma: a risk assessment. Environ Health Perspect 118:818-824. doi:10.1289/ehp.0901388

Liu Y, Chang CC, Marsh GM, Wu F (2012) Population attributable risk of aflatoxin-related liver cancer: systematic review and meta-analysis. Eur J Cancer 48:2125-2136. doi:10.1016/j. ejca.2012.02.009

Liu M, Gao R, Meng Q, Zhang Y, Bi C, Shan A (2014) Toxic effects of maternal zearalenone exposure on intestinal oxidative stress, barrier function, immunological and morphological changes in rats. PLoS ONE 9:e106412. doi:10.1371/journal.pone.0106412

Loiseau N, Debrauwer L, Sambou T, Bouhet S, Miller JD, Martin PG, Viadere JL, Pinton P, Puel O, Pineau T, Tulliez J, Galtier P, Oswald IP (2007) Fumonisin B1 exposure and its selective effect on porcine jejunal segment: sphingolipids, glycolipids and trans-epithelial passage disturbance. Biochem Pharmacol 74:144-152. doi:10.1016/j.bcp.2007.03.031

Loiseau N, Polizzi A, Dupuy A, Therville N, Rakotonirainy M, Loy J, Viadere JL, Cossalter AM, Bailly JD, Puel O, Kolf-Clauw M, Bertrand-Michel J, Levade T, Guillou H, Oswald IP (2015) New insights into the organ-specific adverse effects of fumonisin B1: comparison between lung and liver. Arch Toxicol 89:16191629. doi:10.1007/s00204-014-1323-6

Lucioli J, Pinton P, Callu P, Laffitte J, Grosjean F, Kolf-Clauw M, Oswald IP, Bracarense AP (2013) The food contaminant deoxynivalenol activates the mitogen activated protein kinases in the intestine: interest of ex vivo models as an alternative to in vivo experiments. Toxicon 66:31-36. doi:10.1016/j. toxicon.2013.01.024
Mahfoud R, Maresca M, Garmy N, Fantini J (2002) The mycotoxin patulin alters the barrier function of the intestinal epithelium: mechanism of action of the toxin and protective effects of glutathione. Toxicol Appl Pharmacol 181:209-218. doi:10.1006/ taap.2002.9417

Makela MJ, Eriksson C, Kotaniemi-Syrjanen A, Palosuo K, Marsh J, Borres M, Kuitunen M, Pelkonen AS (2014) Wheat allergy in children - new tools for diagnostics. Clin Exp Allergy 44:1420 1430. doi:10.1111/cea.12393

Malekinejad H, Maas-Bakker RF, Fink-Gremmels J (2005) Bioactivation of zearalenone by porcine hepatic biotransformation. Vet Res 36:799-810. doi:10.1051/vetres:2005034

Malekinejad H, Maas-Bakker RF, Fink-Gremmels J (2006a) Species differences in the hepatic biotransformation of zearalenone. Vet J 172:96-102. doi:10.1016/j.tvj1.2005.03.004

Malekinejad H, Van Tol HT, Colenbrander B, Fink-Gremmels J (2006b) Expression of 3alpha- and 3beta-hydroxy steroid dehydrogenase mRNA in COCs and granulosa cells determines Zearalenone biotransformation. Toxicol In Vitro 20:458-463. doi:10.1016/j.tiv.2005.09.007

Malekinejad H, Schoevers EJ, Daemen IJ, Zijlstra C, Colenbrander B, Fink-Gremmels J, Roelen BA (2007) Exposure of oocytes to the Fusarium toxins zearalenone and deoxynivalenol causes aneuploidy and abnormal embryo development in pigs. Biol Reprod 77:840-847. doi:10.1095/biolreprod.107.062711

Mally A (2012) Ochratoxin a and mitotic disruption: mode of action analysis of renal tumor formation by ochratoxin A. Toxicol Sci 127:315-330. doi:10.1093/toxsci/kfs 105

Manda G, Mocanu MA, Marin DE, Taranu I (2015) Dual effects exerted in vitro by micromolar concentrations of deoxynivalenol on undifferentiated caco-2 cells. Toxins (Basel) 7:593-603. doi:10.3390/toxins7020593

Marasas WF, Riley RT, Hendricks KA, Stevens VL, Sadler TW, Gelineau-van Waes J, Missmer SA, Cabrera J, Torres O, Gelderblom WC, Allegood J, Martinez C, Maddox J, Miller JD, Starr L, Sullards MC, Roman AV, Voss KA, Wang E, Merrill AH Jr (2004) Fumonisins disrupt sphingolipid metabolism, folate transport, and neural tube development in embryo culture and in vivo: a potential risk factor for human neural tube defects among populations consuming fumonisin-contaminated maize. J Nutr 134:711-716

Maresca M (2013) From the gut to the brain: journey and pathophysiological effects of the food-associated trichothecene mycotoxin deoxynivalenol. Toxins (Basel) 5:784-820. doi:10.3390/ toxins 5040784

Maresca M, Fantini J (2010) Some food-associated mycotoxins as potential risk factors in humans predisposed to chronic intestinal inflammatory diseases. Toxicon 56:282-294. doi:10.1016/j. toxicon.2010.04.016

Maresca M, Mahfoud R, Pfohl-Leszkowicz A, Fantini J (2001) The mycotoxin ochratoxin A alters intestinal barrier and absorption functions but has no effect on chloride secretion. Toxicol Appl Pharmacol 176:54-63. doi:10.1006/taap.2001.9254

Maresca M, Mahfoud R, Garmy N, Fantini J (2002) The mycotoxin deoxynivalenol affects nutrient absorption in human intestinal epithelial cells. J Nutr 132:2723-2731

Maresca M, Yahi N, Younes-Sakr L, Boyron M, Caporiccio B, Fantini $\mathrm{J}$ (2008) Both direct and indirect effects account for the proinflammatory activity of enteropathogenic mycotoxins on the human intestinal epithelium: stimulation of interleukin- 8 secretion, potentiation of interleukin-1beta effect and increase in the transepithelial passage of commensal bacteria. Toxicol Appl Pharmacol 228:84-92. doi:10.1016/j.taap.2007.11.013

Marin DE, Taranu I, Burlacu R, Manda G, Motiu M, Neagoe I, Dragomir C, Stancu M, Calin L (2011) Effects of zearalenone and 
its derivatives on porcine immune response. Toxicol In Vitro 25:1981-1988. doi:10.1016/j.tiv.2011.06.022

Marin S, Ramos AJ, Cano-Sancho G, Sanchis V (2013) Mycotoxins: occurrence, toxicology, and exposure assessment. Food Chem Toxicol 60:218-237. doi:10.1016/j.fct.2013.07.047

Marin DE, Motiu M, Taranu I (2015) Food contaminant zearalenone and its metabolites affect cytokine synthesis and intestinal epithelial integrity of porcine cells. Toxins (Basel) 7:1979-1988. doi:10.3390/toxins7061979

Matter K, Balda MS (2003) Signalling to and from tight junctions. Nat Rev Mol Cell Biol 4:225-236. doi:10.1038/nrm1055

McCormick SP, Stanley AM, Stover NA, Alexander NJ (2011) Trichothecenes: from simple to complex mycotoxins. Toxins (Basel) 3:802-814. doi:10.3390/toxins3070802

McLaughlin J, Padfield PJ, Burt JP, O’Neill CA (2004) Ochratoxin A increases permeability through tight junctions by removal of specific claudin isoforms. Am J Physiol Cell Physiol 287:C1412-C1417. doi:10.1152/ajpcell.00007.2004

McLaughlin J, Lambert D, Padfield PJ, Burt JP, O’Neill CA (2009) The mycotoxin patulin, modulates tight junctions in caco-2 cells. Toxicol In Vitro 23:83-89. doi:10.1016/j.tiv.2008.10.009

Meddings JB, Gibbons I (1998) Discrimination of site-specific alterations in gastrointestinal permeability in the rat. Gastroenterology 114:83-92. doi:10.1016/S0016-5085(98)70636-5

Minervini F, Dell'Aquila ME (2008) Zearalenone and reproductive function in farm animals. Int $J$ Mol Sci 9:2570-2584. doi:10.3390/ijms9122570

Missmer SA, Suarez L, Felkner M, Wang E, Merrill AH Jr, Rothman KJ, Hendricks KA (2006) Exposure to fumonisins and the occurrence of neural tube defects along the Texas-Mexico border. Environ Health Perspect 114:237-241. doi:10.1289/ehp.8221

Moake MM, Padilla-Zakour OI, Worobo RW (2005) Comprehensive review of patulin control methods in foods. Compr Rev Food Sci Food Saf 4:8-21. doi:10.1111/j.1541-4337.2005.tb00068.x

Mohan HM, Collins D, Maher S, Walsh EG, Winter DC, O'Brien PJ, Brayden DJ, Baird AW (2012) The mycotoxin patulin increases colonic epithelial permeability in vitro. Food Chem Toxicol 50:4097-4102. doi:10.1016/j.fct.2012.07.036

Mullen TD, Hannun YA, Obeid LM (2012) Ceramide synthases at the centre of sphingolipid metabolism and biology. Biochem $\mathrm{J}$ 441:789-802. doi:10.1042/BJ20111626

Nathanail AV, Syvahuoko J, Malachova A, Jestoi M, Varga E, Michlmayr H, Adam G, Sievilainen E, Berthiller F, Peltonen K (2015) Simultaneous determination of major type A and B trichothecenes, zearalenone and certain modified metabolites in Finnish cereal grains with a novel liquid chromatographytandem mass spectrometric method. Anal Bioanal Chem 407:4745-4755. doi:10.1007/s00216-015-8676-4

Nielsen JK, Vikstrom AC, Turner P, Knudsen LE (2011) Deoxynivalenol transport across the human placental barrier. Food Chem Toxicol 49:2046-2052. doi:10.1016/j.fct.2011.05.016

Nordenstedt H, White DL, El-Serag HB (2010) The changing pattern of epidemiology in hepatocellular carcinoma. Dig Liver Dis 42(Suppl 3):S206-S214. doi:10.1016/S1590-8658(10)60507-5

Odenwald MA, Turner JR (2013) Intestinal permeability defects: is it time to treat? Clin Gastroenterol Hepatol 11:1075-1083. doi:10.1016/j.cgh.2013.07.001

Omar RF, Hasinoff BB, Mejilla F, Rahimtula AD (1990) Mechanism of ochratoxin A stimulated lipid peroxidation. Biochem Pharmacol 40:1183-1191. doi:10.1016/0006-2952(90)90382-U

Osselaere A, Santos R, Hautekiet V, De Backer P, Chiers K, Ducatelle R, Croubels S (2013) Deoxynivalenol impairs hepatic and intestinal gene expression of selected oxidative stress, tight junction and inflammation proteins in broiler chickens, but addition of an adsorbing agent shifts the effects to the distal parts of the small intestine. PLoS ONE 8:e69014. doi:10.1371/journal. pone.0069014

Oswald IP, Desautels C, Laffitte J, Fournout S, Peres SY, Odin M, Le Bars P, Le Bars J, Fairbrother JM (2003) Mycotoxin fumonisin B1 increases intestinal colonization by pathogenic Escherichia coli in pigs. Appl Environ Microbiol 69:5870-5874. doi:10.1128/AEM.69.10.5870-5874.2003

Pastorelli L, De Salvo C, Mercado JR, Vecchi M, Pizarro TT (2013) Central role of the gut epithelial barrier in the pathogenesis of chronic intestinal inflammation: lessons learned from animal models and human genetics. Front Immunol 4:280. doi:10.3389/fimmu.2013.00280

Pelsers MM, Namiot Z, Kisielewski W, Namiot A, Januszkiewicz M, Hermens WT, Glatz JF (2003) Intestinal-type and liver-type fatty acid-binding protein in the intestine. Tissue distribution and clinical utility. Clin Biochem 36:529-535. doi:10.1016/ S0009-9120(03)00096-1

Peraica M, Domijan AM, Matasin M, Lucic A, Radic B, Delas F, Horvat M, Bosanac I, Balija M, Grgicevic D (2001) Variations of ochratoxin A concentration in the blood of healthy populations in some Croatian cities. Arch Toxicol 75:410-414. doi:10.1007/ s002040100258

Pestka JJ (2007) Deoxynivalenol: toxicity, mechanisms and animal health risks. Anim Feed Sci Technol 137:283-298. doi:10.1016/j.anifeedsci.2007.06.006

Pestka JJ (2010a) Deoxynivalenol-induced proinflammatory gene expression: mechanisms and pathological sequelae. Toxins (Basel) 2:1300-1317. doi:10.3390/toxins 2061300

Pestka JJ (2010b) Deoxynivalenol: mechanisms of action, human exposure, and toxicological relevance. Arch Toxicol 84:663679. doi:10.1007/s00204-010-0579-8

Pestka JJ, Moorman MA, Warner RL (1990) Altered serum immunoglobulin response to model intestinal antigens during dietary exposure to vomitoxin (deoxynivalenol). Toxicol Lett 50:75-84. doi:10.1016/0378-4274(90)90254-J

Petermann A, Haase D, Wetzel A, Balavenkatraman KK, Tenev T, Guhrs KH, Friedrich S, Nakamura M, Mawrin C, Bohmer FD (2011) Loss of the protein-tyrosine phosphatase DEP-1/PTPRJ drives meningioma cell motility. Brain Pathol 21:405-418. doi:10.1111/j.1750-3639.2010.00464.x

Peterson LW, Artis D (2014) Intestinal epithelial cells: regulators of barrier function and immune homeostasis. Nat Rev Immunol 14:141-153. doi:10.1038/nri3608

Pfeiffer E, Kommer A, Dempe JS, Hildebrand AA, Metzler M (2011) Absorption and metabolism of the mycotoxin zearalenone and the growth promotor zeranol in Caco-2 cells in vitro. Mol Nutr Food Res 55:560-567. doi:10.1002/mnfr.201000381

Pfenning C, Esch HL, Fliege R, Lehmann L (2014) The mycotoxin patulin reacts with DNA bases with and without previous conjugation to GSH: implication for related alpha, betaunsaturated carbonyl compounds? Arch Toxicol. doi:10.1007/ s00204-014-1443-z

Pfohl-Leszkowicz A, Manderville RA (2007) Ochratoxin A: an overview on toxicity and carcinogenicity in animals and humans. Mol Nutr Food Res 51:61-99. doi:10.1002/mnfr.200600137

Pfohl-Leszkowicz A, Manderville RA (2012) An update on direct genotoxicity as a molecular mechanism of ochratoxin a carcinogenicity. Chem Res Toxicol 25:252-262. doi:10.1021/ tx200430f

Pfohl-Leszkowicz A, Chekir-Ghedira L, Bacha H (1995) Genotoxicity of zearalenone, an estrogenic mycotoxin: DNA adduct formation in female mouse tissues. Carcinogenesis 16:2315-2320. doi: $10.1093 / \mathrm{carcin} / 16.10 .2315$

Pinton P, Oswald IP (2014) Effect of deoxynivalenol and other Type $B$ trichothecenes on the intestine: a review. Toxins (Basel) 6:1615-1643. doi:10.3390/toxins6051615 
Pinton P, Nougayrede JP, Del Rio JC, Moreno C, Marin DE, Ferrier L, Bracarense AP, Kolf-Clauw M, Oswald IP (2009) The food contaminant deoxynivalenol, decreases intestinal barrier permeability and reduces claudin expression. Toxicol Appl Pharmacol 237:41-48. doi:10.1016/j.taap.2009.03.003

Pinton P, Braicu C, Nougayrede JP, Laffitte J, Taranu I, Oswald IP (2010) Deoxynivalenol impairs porcine intestinal barrier function and decreases the protein expression of claudin- 4 through a mitogen-activated protein kinase-dependent mechanism. J Nutr 140:1956-1962. doi:10.3945/jn.110.123919

Pinton P, Tsybulskyy D, Lucioli J, Laffitte J, Callu P, Lyazhri F, Grosjean F, Bracarense AP, Kolf-Clauw M, Oswald IP (2012) Toxicity of deoxynivalenol and its acetylated derivatives on the intestine: differential effects on morphology, barrier function, tight junction proteins, and mitogen-activated protein kinases. Toxicol Sci 130:180-190. doi:10.1093/toxsci/kfs239

Pinton P, Graziani F, Pujol A, Nicoletti C, Paris O, Ernouf P, Di Pasquale E, Perrier J, Oswald IP, Maresca M (2015) Deoxynivalenol inhibits the expression by goblet cells of intestinal mucins through a PKR and MAP kinase dependent repression of the resistin-like molecule beta. Mol Nutr Food Res 59:1076-1087. doi:10.1002/mnfr.201500005

Plotnikov A, Zehorai E, Procaccia S, Seger R (2011) The MAPK cascades: signaling components, nuclear roles and mechanisms of nuclear translocation. Biochim Biophys Acta 1813:1619-1633. doi:10.1016/j.bbamcr.2010.12.012

Prasad S, Mingrino R, Kaukinen K, Hayes KL, Powell RM, MacDonald TT, Collins JE (2005) Inflammatory processes have differential effects on claudins 2, 3 and 4 in colonic epithelial cells. Lab Invest 85:1139-1162. doi:10.1038/labinvest.3700316

Puel O, Galtier P, Oswald IP (2010) Biosynthesis and toxicological effects of patulin. Toxins (Basel) 2:613-631. doi:10.3390/ toxins 2040613

Ranaldi G, Mancini E, Ferruzza S, Sambuy Y, Perozzi G (2007) Effects of red wine on ochratoxin A toxicity in intestinal Caco-2/TC7 cells. Toxicol In Vitro 21:204-210. doi:10.1016/j. tiv.2006.09.005

Randall KJ, Turton J, Foster JR (2011) Explant culture of gastrointestinal tissue: a review of methods and applications. Cell Biol Toxicol 27:267-284. doi:10.1007/s10565-011-9187-5

Rheder JP, Marasas WFO, Thiel PG, Sydenham EW, Shephard GS, van Schalkwyk DJ (1992) Fusarium moniliforme and fumonisins in corn in relation to human esophageal cancer in Transkei. Phytopathology 82:353-357. doi:10.1094/Phyto-82-353

Ribeiro DH, Ferreira FL, da Silva VN, Aquino S, Correa B (2010) Effects of aflatoxin B1 and fumonisin B1 on the viability and induction of apoptosis in rat primary hepatocytes. Int J Mol Sci 11:1944-1955. doi:10.3390/ijms11041944

Rocha O, Ansari K, Doohan FM (2005) Effects of trichothecene mycotoxins on eukaryotic cells: a review. Food Addit Contam 22:369-378. doi:10.1080/02652030500058403

Rodrigues I, Naehrer K (2012) A three-year survey on the worldwide occurrence of mycotoxins in feedstuffs and feed. Toxins (Basel) 4:663-675. doi:10.3390/toxins4090663

Romero A, Ares I, Ramos E, Castellano V, Martinez M, Martinez-Larranaga MR, Anadon A, Martinez MA (2016) Mycotoxins modify the barrier function of Caco- 2 cells through differential gene expression of specific claudin isoforms: protective effect of illite mineral clay. Toxicology 353-354:21-33. doi:10.1016/j. tox.2016.05.003

Rotter BA, Prelusky DB, Pestka JJ (1996) Toxicology of deoxynivalenol (vomitoxin). J Toxicol Environ Health 48:1-34. doi:10.1080/713851046

Sadler TW, Merrill AH, Stevens VL, Sullards MC, Wang E, Wang P (2002) Prevention of fumonisin B1-induced neural tube defects by folic acid. Teratology 66:169-176. doi:10.1002/tera.10089
Sambuy Y, De Angelis I, Ranaldi G, Scarino ML, Stammati A, Zucco F (2005) The Caco-2 cell line as a model of the intestinal barrier: influence of cell and culture-related factors on Caco-2 cell functional characteristics. Cell Biol Toxicol 21:1-26. doi:10.1007/s10565-005-0085-6

Sarkanj B, Warth B, Uhlig S, Abia WA, Sulyok M, Klapec T, Krska R, Banjari I (2013) Urinary analysis reveals high deoxynivalenol exposure in pregnant women from Croatia. Food Chem Toxicol 62:231-237. doi:10.1016/j.fct.2013.08.043

Schebb NH, Faber H, Maul R, Heus F, Kool J, Irth H, Karst U (2009) Analysis of glutathione adducts of patulin by means of liquid chromatography (HPLC) with biochemical detection (BCD) and electrospray ionization tandem mass spectrometry (ESIMS/MS). Anal Bioanal Chem 394:1361-1373. doi:10.1007/ s00216-009-2765-1

Schneeberger EE, Lynch RD (2004) The tight junction: a multifunctional complex. Am J Physiol Cell Physiol 286:C1213-C1228. doi:10.1152/ajpcell.00558.2003

Schoevers EJ, Santos RR, Colenbrander B, Fink-Gremmels J, Roelen BA (2012) Transgenerational toxicity of Zearalenone in pigs. Reprod Toxicol 34:110-119. doi:10.1016/j. reprotox.2012.03.004

Schrickx J, Lektarau Y, Fink-Gremmels J (2006) Ochratoxin A secretion by ATP-dependent membrane transporters in Caco- 2 cells. Arch Toxicol 80:243-249. doi:10.1007/s00204-005-0041-5

Schwanhausser B, Busse D, Li N, Dittmar G, Schuchhardt J, Wolf J, Chen W, Selbach M (2011) Global quantification of mammalian gene expression control. Nature 473:337-342. doi:10.1038/ nature 10098

Sergent T, Garsou S, Schaut A, De Saeger S, Pussemier L, Van Peteghem C, Larondelle Y, Schneider YJ (2005) Differential modulation of ochratoxin A absorption across Caco-2 cells by dietary polyphenols, used at realistic intestinal concentrations. Toxicol Lett 159:60-70. doi:10.1016/j.toxlet.2005.04.013

Sergent T, Parys M, Garsou S, Pussemier L, Schneider YJ, Larondelle Y (2006) Deoxynivalenol transport across human intestinal Caco-2 cells and its effects on cellular metabolism at realistic intestinal concentrations. Toxicol Lett 164:167-176. doi:10.1016/j.toxlet.2005.12.006

Shank RA, Foroud NA, Hazendonk P, Eudes F, Blackwell BA (2011) Current and future experimental strategies for structural analysis of trichothecene mycotoxins: a prospectus. Toxins (Basel) 3:1518-1553. doi:10.3390/toxins 3121518

Shimizu M (2010) Interaction between food substances and the intestinal epithelium. Biosci Biotechnol Biochem 74:232-241

Sievers S, Rawel HM, Ringel KP, Niggemann B, Beyer K (2015) Wheat protein recognition pattern in tolerant and allergic children. Pediatr Allergy Immunol. doi:10.1111/pai.12502

Sobrova P, Adam V, Vasatkova A, Beklova M, Zeman L, Kizek R (2010) Deoxynivalenol and its toxicity. Interdiscip Toxicol 3:94-99. doi:10.2478/v10102-010-0019-x

Sorrenti V, Di Giacomo C, Acquaviva R, Barbagallo I, Bognanno M, Galvano F (2013) Toxicity of ochratoxin a and its modulation by antioxidants: a review. Toxins (Basel) 5:1742-1766. doi:10.3390/toxins5101742

Studer-Rohr I, Schlatter J, Dietrich DR (2000) Kinetic parameters and intraindividual fluctuations of ochratoxin A plasma levels in humans. Arch Toxicol 74:499-510. doi:10.1007/ s002040000157

Sudakin DL (2003) Trichothecenes in the environment: relevance to human health. Toxicol Lett 143:97-107. doi:10.1016/ S0378-4274(03)00116-4

Sun H, Pang KS (2007) Permeability, transport, and metabolism of solutes in Caco-2 cell monolayers: a theoretical study. Drug Metab Dispos 36:102-123. doi:10.1124/dmd.107.015321 
Sun H, Chow EC, Liu S, Du Y, Pang KS (2008) The Caco-2 cell monolayer: usefulness and limitations. Expert Opin Drug Metab Toxicol 4:395-411. doi:10.1517/17425255.4.4.395

Sun M, Fu H, Cheng H, Cao Q, Zhao Y, Mou X, Zhang X, Liu X, Ke Y (2012) A dynamic real-time method for monitoring epithelial barrier function in vitro. Anal Biochem 425:96-103. doi:10.1016/j.ab.2012.03.010

Suzuki T (2013) Regulation of intestinal epithelial permeability by tight junctions. Cell Mol Life Sci 70:631-659. doi:10.1007/ s00018-012-1070-x

Sydenham EW, Thiel PG, Marasas WFO, Shephard GS, Van Schalkwyk DJ, Koch KR (1990) Natural occurrence of some Fusarium mycotoxins in corn from low and high esophageal cancer prevalence areas of the Transkei, Southern Africa. J Agric Food Chem 38:1900-1903. doi:10.1021/jf00100a004

Szakal DN, Gyorffy H, Arato A, Cseh A, Molnar K, Papp M, Dezsofi A, Veres G (2010) Mucosal expression of claudins 2, 3 and 4 in proximal and distal part of duodenum in children with coeliac disease. Virchows Arch 456:245-250. doi:10.1007/ s00428-009-0879-7

Takemura H, Shim JY, Sayama K, Tsubura A, Zhu BT, Shimoi K (2007) Characterization of the estrogenic activities of zearalenone and zeranol in vivo and in vitro. J Steroid Biochem Mol Biol 103:170-177. doi:10.1016/j.jsbmb.2006.08.008

Tep J, Videmann B, Mazallon M, Balleydier S, Cavret S, Lecoeur S (2007) Transepithelial transport of fusariotoxin nivalenol: mediation of secretion by ABC transporters. Toxicol Lett 170:248258. doi:10.1016/j.toxlet.2007.03.012

Tsukita S, Furuse M, Itoh M (2001) Multifunctional strands in tight junctions. Nat Rev Mol Cell Biol 2:285-293. doi: $10.1038 / 35067088$

Turner PC, Ji BT, Shu XO, Zheng W, Chow WH, Gao YT, Hardie LJ (2011) A biomarker survey of urinary deoxynivalenol in China: the Shanghai Women's Health Study. Food Addit Contam Part A 28:1220-1223. doi:10.1080/19440049.2011.584070

Vandenbroucke V, Croubels S, Martel A, Verbrugghe E, Goossens J, Van Deun K, Boyen F, Thompson A, Shearer N, De Backer P, Haesebrouck F, Pasmans F (2011) The mycotoxin deoxynivalenol potentiates intestinal inflammation by Salmonella typhimurium in porcine ileal loops. PLoS ONE 6:e23871. doi:10.1371/ journal.pone. 0023871

Verbrugghe E, Vandenbroucke V, Dhaenens M, Shearer N, Goossens J, De Saeger S, Eeckhout M, D'Herde K, Thompson A, Deforce D, Boyen F, Leyman B, Van Parys A, De Backer P, Haesebrouck F, Croubels S, Pasmans F (2012) T-2 toxin induced Salmonella Typhimurium intoxication results in decreased Salmonella numbers in the cecum contents of pigs, despite marked effects on Salmonella-host cell interactions. Vet Res 43:22. doi:10.1186/1297-9716-43-22

Vetrano S, Rescigno M, Cera MR, Correale C, Rumio C, Doni A, Fantini M, Sturm A, Borroni E, Repici A, Locati M, Malesci A, Dejana E, Danese S (2008) Unique role of junctional adhesion molecule-a in maintaining mucosal homeostasis in inflammatory bowel disease. Gastroenterology 135:173-184. doi:10.1053/j.gastro.2008.04.002

Videmann B, Tep J, Cavret S, Lecoeur S (2007) Epithelial transport of deoxynivalenol: involvement of human P-glycoprotein
(ABCB1) and multidrug resistance-associated protein 2 (ABCC2). Food Chem Toxicol 45:1938-1947. doi:10.1016/j. fct.2007.04.011

Videmann B, Mazallon M, Prouillac C, Delaforge M, Lecoeur S (2009) ABCC1, ABCC2 and ABCC 3 are implicated in the transepithelial transport of the myco-estrogen zearalenone and its major metabolites. Toxicol Lett 190:215-223. doi:10.1016/j. toxlet.2009.07.021

Vogel C, Abreu Rde S, Ko D, Le SY, Shapiro BA, Burns SC, Sandhu D, Boutz DR, Marcotte EM, Penalva LO (2010) Sequence signatures and mRNA concentration can explain two-thirds of protein abundance variation in a human cell line. Mol Syst Biol 6:400. doi:10.1038/msb.2010.59

Voss KA, Smith GW, Haschek WM (2007) Fumonisins: toxicokinetics, mechanism of action and toxicity. Anim Feed Sci Technol 137:299-325. doi:10.1016/j.anifeedsci.2007.06.007

Wang Z, Wu Q, Kuca K, Dohnal V, Tian Z (2014) Deoxynivalenol: signaling pathways and human exposure risk assessment-an update. Arch Toxicol 88:1915-1928. doi:10.1007/ s00204-014-1354-Z

Warth B, Sulyok M, Fruhmann P, Berthiller F, Schuhmacher R, Hametner C, Adam G, Frohlich J, Krska R (2012) Assessment of human deoxynivalenol exposure using an LC-MS/MS based biomarker method. Toxicol Lett 211:85-90. doi:10.1016/j. toxlet.2012.02.023

Warth B, Sulyok M, Berthiller F, Schuhmacher R, Krska R (2013) New insights into the human metabolism of the Fusarium mycotoxins deoxynivalenol and zearalenone. Toxicol Lett 220:88-94. doi:10.1016/j.toxlet.2013.04.012

Wild CP, Turner PC (2002) The toxicology of aflatoxins as a basis for public health decisions. Mutagenesis 17:471-481. doi:10.1093/ mutage/17.6.471

Wu HC, Santella R (2012) The role of aflatoxins in hepatocellular carcinoma. Hepat Mon 12:e7238. doi:10.5812/hepatmon.7238

Wu Q, Dohnal V, Kuca K, Yuan Z (2013) Trichothecenes: structuretoxic activity relationships. Curr Drug Metab 14:641-660

Wu F, Groopman JD, Pestka JJ (2014a) Public health impacts of foodborne mycotoxins. Annu Rev Food Sci Technol 5:351-372. doi:10.1146/annurev-food-030713-092431

Wu QH, Wang X, Yang W, Nussler AK, Xiong LY, Kuca K, Dohnal V, Zhang XJ, Yuan ZH (2014b) Oxidative stress-mediated cytotoxicity and metabolism of T-2 toxin and deoxynivalenol in animals and humans: an update. Arch Toxicol 88:1309-1326. doi:10.1007/s00204-014-1280-0

Yazar S, Omurtag GZ (2008) Fumonisins, trichothecenes and zearalenone in cereals. Int J Mol Sci 9:2062-2090. doi:10.3390/ ijms9112062

Zeissig S, Burgel N, Gunzel D, Richter J, Mankertz J, Wahnschaffe U, Kroesen AJ, Zeitz M, Fromm M, Schulzke JD (2007) Changes in expression and distribution of claudin 2, 5 and 8 lead to discontinuous tight junctions and barrier dysfunction in active Crohn's disease. Gut 56:61-72. doi:10.1136/gut.2006.094375

Zinedine A, Soriano JM, Molto JC, Manes J (2007) Review on the toxicity, occurrence, metabolism, detoxification, regulations and intake of zearalenone: an oestrogenic mycotoxin. Food Chem Toxicol 45:1-18. doi:10.1016/j.fct.2006.07.030 